\title{
La asistencia jurídica en el procedimiento administrativo
}

\author{
José Vicente Lorenzo Jiménez \\ Profesor Asociado de Derecho Administrativo \\ Universidad de Sevilla
}

SUMARIO: I. LAS PREVISIONES CONSTITUCIONALES. 1. Aspectos generales. 2. El art. 17.3 de la Constitución. 3. El art. 24.2 de la Constitución. 4. El art. 119 de la Constitución. 5. La no previsión constitucional en la vía administrativa. 6. Las previsiones de los textos internacionales. II. LA REGLA GENERAL: LA PREVISIÓN GENERAL DE ASESORAMIENTO. 1. Las previsiones generales sobre asesoramiento y asistencia en el procedimiento administrativo. 2. El asesoramiento en el procedimiento administrativo sancionador. 3. Naturaleza jurídica de la asistencia jurídica. 4. La lesión del derecho a la asistencia jurídica. 5. ¿Está reservada la asistencia jurídica en el procedimiento administrativo a los abogados? 6 . ¿Debe contemplarse expresamente la intervención de abogado en el procedimiento administrativo? III. LA PREVISIÓN DE LA INTERVENGIÓN DE ASESOR EN NORMAS ESPECÍFICAS. 1. Las previsiones en la legislación penitenciaria. 2. El régimen disciplinario de las Fuerzas Armadas. El régimen disciplinario de la Guardia Civil. 4. El régimen disciplinario de la policía nacional. 5. Las previsiones de la Ley Orgánica del Poder Judicial. 6. La legislación reguladora del derecho de asilo y de la condición de refugiado. IV. LA PREVISIÓN EXPRESA DE LA INTERVENCIÓN DE LETRADO CON EL ACENTO EN LA ASISTENCIA JURÍDICA GRATUITA. 1. La Ley de Asistencia Jurídica Gratuita. 2. La legislación de extranjería. 3. La Ley de Violencia de Género. V. LA NO PREVISIÓN DE LA INTERVENGIÓN DE LETRADO EN LOS SUPUESTOS DE DETENGIÓN POR INFRACGIÓN DE LA LEGISLACIÓN ADMINISTRATIVA. 


\section{RESUMEN}

El presente trabajo tiene por objeto estudiar la asistencia jurídica en el procedimiento administrativo. Se analiza en primer lugar si es posible hablar de un derecho constitucional a la asistencia jurídica en el procedimiento administrativo, y su relación con el derecho a la asistencia jurídica gratuita. A continuación se examina la regulación de la asistencia jurídica en la Ley 30/1992, contemplada con carácter general como el derecho a contar con asesor, analizándose la jurisprudencia sobre la materia. Posteriormente se examina la regulación de la materia por normas específicas, en las que se contempla expresamente la intervención de determinadas personas para facilitar el derecho a la defensa. Asimismo se analizan las normas que dan un paso más y contemplan un derecho a la asistencia jurídica gratuita en el procedimiento administrativo.

Palabras clave: Defensa y asistencia jurídica, procedimiento administrativo, abogado, asesor.

\section{ABSTRACT}

The present paper has for object to study legal assistance in the administrative procedure. It examines if legal advice in administrative proceedings is a constitutional right, and their relationship with the right to legal aid. It below examines legal assistance in Law 30/1992, which regulates in general the right to consultant, analyzing case law on the matter. Subsequently it examines specific rules, which expressly provides for the involvement of certain individuals to facilitate the right to defense. It also studies the rules that include a right to free assistance in administrative procedures.

Key words: Defence and assistance of a lawyer, administrative procedure, lawyer, consultant.

\section{LAS PREVISIONES CONSTITUGIONALES ${ }^{1}$}

\section{Aspectos generales}

La Constitución (en adelante, CE) no dedica ningún precepto a la asistencia jurídica en el procedimiento administrativo. El art. 105.c) se limita a decir, con carácter genérico, que la ley regulará el procedimiento a través del cual deben producirse los actos administrativos, garantizando, cuando proceda, la audiencia

${ }^{1}$ El presente trabajo ha sido redactado en homenaje al Profesor D. Alfonso Pérez Moreno, Maestro del Derecho Administrativo y Maestro en el más amplio sentido de la palabra. 
del interesado. Hay, pues, una remisión genérica a la ley, que, en principio, es la que debe concretar, en su caso, la existencia y el ámbito de la asistencia jurídica.

\section{El art. 17.3 de la Constitución}

El art. 17.3 CE dice que toda persona detenida deberá ser informada de forma inmediata, y de modo que le sea comprensible, de sus derechos y de las razones de su detención, no pudiendo ser obligada a declarar, añadiendo que se garantiza la asistencia de abogado al detenido en las diligencias policiales y judiciales en los términos que la ley establezca.

El precepto contempla, pues, la posibilidad de una detención, que puede dar lugar a diligencias policiales o judiciales, lo que permite entender que la detención puede tener un carácter administrativo o un carácter judicial. En ambos casos se prevé la asistencia de abogado al detenido.

No obstante, en la jurisprudencia constitucional, como más adelante veremos, se ha planteado la cuestión del concepto de detención; así como la de si es aplicable el art. 17 a las detenciones no procesales.

\section{El art. 24.2 de la Constitución}

$\mathrm{El}$ art. 24.2 CE contiene una serie de derechos fundamentales de carácter garantizador. En principio, todos ellos están referidos al proceso judicial, no al procedimiento administrativo. Entre estos derechos se encuentra el derecho a la defensa y a la asistencia letrada². De acuerdo con la doctrina del Tribunal Constitucional, tales derechos se refieren fundamentalmente a los procesos penales. Así, según la sentencia de este Tribunal (en adelante, STC) 42/82, en principio el derecho a la asistencia de letrado, al igual que los contemplados en el art. 24.2 CE, se refiere fundamentalmente al proceso penal.

No obstante, también ha entendido que este derecho es aplicable al resto de los procesos judiciales, aunque con matices. La STC 47/87 dice que el art. 24.2 tiene una proyección especial hacia el proceso penal, pero es también de aplicación a los demás procesos, añadiendo que la finalidad de la asistencia jurídica es la de asegurar la igualdad de las partes y de contradicción, evitando situaciones de indefensión ${ }^{3}$.

\footnotetext{
${ }^{2}$ Puede verse un resumen de la doctrina del Tribunal Constitucional sobre el derecho a la asistencia letrada en GARBERÍ LLOBREGAT, J., Constitución y Derecho Procesal. Los fundamentos constitucionales del Derecho Procesal, Cuadernos Civitas, Madrid 2009, pág. 246 ss.

${ }^{3}$ En igual sentido otras muchas sentencias. Vid, por ejemplo, STC 174/09.
} 
En consecuencia, el derecho a la asistencia jurídica no se extiende a los procedimientos administrativos. Sólo excepcionalmente el Tribunal Constitucional lo ha extendido a determinados procedimientos administrativos sancionadores (principalmente, procedimientos disciplinarios en centros penitenciarios). En este sentido, el Tribunal Constitucional ha sido, con carácter general, muy restrictivo, de manera que las garantías del $24 \mathrm{CE}$ solo se aplican a los procedimientos administrativos en la medida necesaria para preservar los valores esenciales que se encuentran en la base del precepto, y la seguridad jurídica que garantiza el art. 9 CE (STG 18/81).

No obstante, ante determinados supuestos el Tribunal Constitucional ha matizado estas ideas. Así, ha dicho que, aunque el art. 24.2 contempla de forma directa e inmediata el derecho a la tutela judicial efectiva y a determinadas garantías de tipo procesal con especial referencia al orden penal, sin embargo los principios inspiradores del orden penal son de aplicación, con ciertos matices, al Derecho administrativo sancionador, dado que ambos son manifestación del poder punitivo del Estado (vid. STG 18/81, 58/89, 212/90). En igual sentido, cuando la Administración actúa en uso de su potestad sancionadora, debe respetarse el derecho de defensa del art. 24 y con más motivo cuando se trata de sanciones que implican, como en el caso del procedimiento penitenciario disciplinario, una grave restricción de la ya restringida libertad inherente al cumplimiento de una pena (STC 74/85, 192/87).

Baste por ahora con esta doctrina constitucional, sin perjuicio de que más adelante nos extendamos sobre la cuestión al analizar determinadas clases de procedimientos administrativos.

\section{El art. 119 de la Constitución}

$\mathrm{El}$ art. 119 de la Constitución dice que "la justicia será gratuita cuando así lo disponga la ley, y, en todo caso, respecto de quienes acrediten insuficiencia de recursos para litigar".

Puede observarse que el precepto no se refiere directamente a la asistencia jurídica, pero es indudable que, tal como está planteado el proceso, en el que, como regla general es necesaria la intervención de abogado y, en su caso, de procurador, uno de los elementos fundamentales para la justicia gratuita es la asistencia jurídica gratuita, ya que, en caso contrario, la falta de medios económicos impediría la intervención en el proceso judicial.

El derecho a la asistencia jurídica gratuita presenta una relación instrumen- 
tal con el derecho a la tutela judicial efectiva (STC 95/2003, 117/98, 183/2001). Su finalidad es que nadie quede procesalmente indefenso por carecer de recursos para litigar (STG 16/94). Pero también es instrumento y concreción del derecho a la asistencia letrada (STC 9/2008).

De acuerdo con una interpretación gramatical de la norma constitucional, la gratuidad se refiere a la justicia, a los efectos de litigar, es decir, se refiere a actuaciones realizadas ante los órganos integrantes del Poder Judicial. Una interpretación sistemática de la norma así lo confirma, al estar incluida en el Título VI, que regula el Poder Judicial.

La STC 16/94 razona que el derecho a la asistencia jurídica gratuita es un derecho prestacional y de configuración legal, cuyo contenido y concretas condiciones de ejercicio corresponde delimitar al legislador, atendiendo a los intereses públicos y privados y a las concretas disponibilidades presupuestarias. Sin embargo, debe respetar un contenido constitucional indisponible, por ser concreción y garantía de otros derechos fundamentales, algunos de contenido no prestacional. En igual sentido se pronuncia la STC 97/2001.

La STC 111/95 (que se remite a la 217/94) es aún más rigurosa. El derecho a abogado y procurador de oficio solo despliega su plena eficacia en relación con el imputado en un proceso penal, siendo en los demás casos un derecho relativo sometido a diversos condicionantes procesales y materiales. Así ocurre, según la citada sentencia, cuando el órgano judicial excluye ab initio el carácter delictivo de un hecho, pues en tal caso tales nombramientos podrían resultar no sólo innecesarios, sino incluso inconvenientes por razones de economía procesal.

Partiendo de este presupuesto, el Tribunal Constitucional ha afirmado que no cabe invocar un derecho a la asistencia jurídica gratuita en la vía administrativa.

Así, la STC 83/97 dice que el contenido del derecho fundamental a la asistencia letrada no implica el reconocimiento del derecho a la asistencia jurídica gratuita durante el procedimiento administrativo (por todas, STC 74/1985, 2/1987, 229/1993), lo que no contradice el art. 24.2 de la Constitución, pues, como resulta del art. 6.3 del Convenio Europeo de Derechos Humanos $(\mathrm{CEDH})$, tal derecho a la gratuidad de la asistencia letrada sólo existe en los procesos judiciales y, además, no en todos, sino sólo cuando el derecho de defensa y los intereses de la justicia lo requieran ${ }^{4}$.

\footnotetext{
${ }^{4}$ La STC 42/08 afirma que el derecho a la asistencia letrada en el procedimiento disciplinario penitenciario no se trata de un derecho a la asistencia letrada, entendida como un derecho pleno a la asisten-
} 
De todo ello cabe concluir que para el Tribunal Constitucional la Constitución no contempla un derecho a la asistencia jurídica gratuita fuera del ámbito de lo jurisdiccional. Lo que significa que, en caso de que el legislador regule un derecho a la asistencia jurídica gratuita en el procedimiento administrativo, no se trata de un derecho de un derecho fundamental.

\section{La no previsión constitucional en la vía administrativa}

Por tanto, la Constitución no contempla directamente el derecho a una serie de garantías procedimentales en el procedimiento administrativo, y en particular el derecho a la defensa y a la asistencia jurídica gratuita.

\section{Las previsiones de los textos internacionales}

Los textos internacionales sólo contemplan el derecho a la asistencia jurídica cuando se trata de un procedimiento penal. Así el art. 14.3.d) del Pacto Internacional de Derechos Civiles y Políticos dice que, durante el proceso, toda persona acusada de un delito tendrá derecho, en plena igualdad, a las siguientes garantías mínimas: d) ... a ser asistida por un defensor de su elección; a ser informada, si no tuviera defensor, del derecho que le asiste a tenerlo y, siempre que el interés de la justicia lo exija, a que se le nombre defensor de oficio, gratuitamente, si careciere de medios suficientes para pagarlo"

Por su parte, el art. 6.3.c) CEDH dice que todo acusado tiene como mínimo los siguientes derechos: a defenderse por sí mismo o a ser asistido por un defensor de su elección; y, si no tiene medios para pagarlo, poder ser asistido gratuitamente por un abogado de oficio, cuando los intereses de la justicia lo exijan".

Como puede observarse, el CEDH solo reconoce un derecho a la asistencia jurídica en los procesos penales, y exclusivamente a los acusados. Ello ya de por sí excluye los demás tipos de procesos. Sin embargo, la jurisprudencia del Tribunal Europeo ha extendido el ámbito de aplicación del art. 6 a determinados procedimientos administrativos sancionadores ${ }^{5}$. Ello podría dar pie

cia de Letrado, incluyendo el derecho a la asistencia jurídica gratuita en caso de necesidad si se carece de medios económicos suficientes para ello, ya que tal derecho, como resulta del art. 6.3 CEDH, sólo existe en los procesos judiciales y además no en todos los casos, sino cuando los intereses de la justicia lo requieran (STC 2/1987, 128/1996, 229/1993, 83/1997, 104/2003), añadiendo que este derecho en los procedimientos de imposición de sanciones a los internos, tanto en su fase ante la Administración penitenciaria como ante el Juzgado de Vigilancia Penitenciaria, no implica la designación de abogado del turno de oficio.

${ }^{5}$ MORENO TRAPIELLA, P., El control judicial de las sanciones administrativas en el convenio europeo de derechos humanos, Documentación Administrativa, 280-281, 2008, pág. 323 ss. 
para entender que el derecho a la asistencia jurídica -incluso gratuita- se extiende a este tipo de procedimientos. En este punto, los criterios del Tribunal Europeo de Derechos Humanos para determinar la expresión cuando los intereses de la justicia lo exijan son la gravedad del delito y la severidad de la sanción a imponer, así como la complejidad del asunto, añadiendo que "cuando está en juego una privación de libertad, los intereses de la justicia imponen, por principio, la asistencia de un abogado" 6 .

\section{LA REGLA GENERAL: LA PREVISIÓN GENERAL DE ASE- SORAMIENTO}

\section{Las previsiones generales sobre asesoramiento y asistencia en el procedimiento administrativo}

A) Es absolutamente excepcional el que en un procedimiento administrativo sea exigible la intervención de Letrado ${ }^{7}$.

\footnotetext{
${ }^{6}$ Caso Mato Jara contra España, decisión de 27-04-2004, Ar. 2004/164183. En este caso considera que el arresto de fin de semana constituye una pena privativa de libertad. La cuestión puede ser importante en determinados procedimientos sancionadores.

${ }^{7}$ Un ejemplo de ello -que ya no está vigente, al haber sido derogado por la Ley 25/95 de 20 de julio- es el de las reclamaciones económico administrativas reguladas por el Real Decreto Legislativo 2795/1980, de 12 de diciembre. Según su art. 13, cuando el interesado en la reclamación económico administrativa no actúe por sí o por medio de su representante legal y el mandato no sea el propio de los administradores, gerentes o directores de sociedades, deberá asumir la dirección técnico jurídica del asunto un abogado en ejercicio en el lugar donde tenga su sede el Tribunal Económico Administrativo respectivo; será necesaria igualmente la intervención de abogado cuado se solicite vista pública, en los recursos extraordinarios de revisión y en los ordinarios de alzada, siempre que en estos últimos el acto administrativo impugnado derive directamente de un expediente calificado como defraudación o exceda de la cuantía que reglamentariamente se determine. Este precepto fue desarrollado por el art. 38 del Reglamento de procedimiento en las reclamaciones económico administrativas (Real Decreto 1999/81 de 20 de agosto). Posteriormente el art. 97.5 del nuevo Reglamento (Real Decreto 391/96 de 1 de marzo) limitó la exigencia de abogado a los casos de celebración de vista pública, cuya solicitud debía ser firmada por letrado. Todos estos preceptos han sido derogados por la Ley 58/2003, de 17 de diciembre, General Tributaria y el Real Decreto 520/2005, de 13 de mayo, que aprueba el Reglamento de desarrollo de la Ley General Tributaria en materia de revisión en vía administrativa. Aquellos preceptos han sido duramente criticados por GONZÁLEZ NAVARRO, que los considera una manifestación de corporativismo en su más rechazable y negativa versión, ansia de justificar una intervención que en ningún caso va a ser gratuita $(D e-$ recho Administrativo español, tomo III, EUNSA, Pamplona, 1997, pág. 642). Por lo demás, suponen una indudable excepción a los principios de informalidad y gratuidad que rigen el procedimiento administrativo, posiblemente motivado por una intención de judicializar este procedimiento, a semejanza del contencioso administrativo. Por su parte, el art. 14.2.e) del Texto Refundido de la Ley de Haciendas Locales, al regular el recurso de reposición contra actos relativos a ingresos de Derecho público de las entidades locales, rechaza expresamente que sea preceptiva la intervención de abogado o procurador.
} 
En tal caso la intervención del letrado no constituiría un derecho, sino una carga, ya que supondría la necesidad de actuar de una determinada manera para obtener un beneficio.

B) En nuestra legislación no se contempla específicamente un derecho a la asistencia jurídica en el procedimiento administrativo. En concreto, nada dice el art. 35 de la Ley de régimen jurídico de las Administraciones públicas y del procedimiento administrativo común (en adelante, LRJ). Es más, este precepto parte de la base de que los interesados tienen derecho a ser asesorados por la propia Administración. En este sentido, las autoridades y funcionarios habrán de facilitarles el ejercicio de sus derechos y el cumplimiento de sus obligaciones (art. 35.i) Asimismo, los ciudadanos tienen derecho, en sus relaciones con las Administraciones públicas, a obtener información y orientación acerca de los requisitos jurídicos o técnicos que las disposiciones vigentes impongan a los proyectos, actuaciones o solicitudes que se propongan realizar (art. 35.g). Desde otro punto de vista, el art. 71.3 incluso prevé que, en los procedimientos iniciados a instancia de los interesados, el órgano competente pueda recabar del solicitante la modificación o mejora voluntaria de los términos de aquella ${ }^{8}$.

No obstante, la Ley 30/1992 recoge una serie de preceptos que permiten la intervención, con carácter general, de terceros que actúen como asesores, entre los que indudablemente cabe incluir los técnicos o asesores en Derecho.

C) Así, el art. 85.2 LRJ contempla la figura del asesor, lo que supone una importante novedad con respecto a la Ley de Procedimiento Administrativo de 1958: los interesados podrán, en todo caso, actuar asistidos de asesor cuando lo consideren conveniente en defensa de sus intereses ${ }^{9}$. Para GONZÁLEZ NAVARRO el asesor es un técnico, no necesariamente titulado, que acompaña al interesado y que para el caso podrá actuar -aun sin ser representante procesal- como un alter ego del interesado que lo presenta. Asesor -añade- puede serlo cualquiera, con título o sin él, y nada impone que tenga una determinada profesión (por ejemplo, abogado, graduado social o gestor administrativo) ${ }^{10}$.

\footnotetext{
${ }^{8}$ En el ámbito tributario se recogen similares previsiones: constituyen derechos de los obligados tributarios el de ser informados y asistidos por la Administración tributaria sobre el ejercicio de sus derechos y el cumplimiento de sus obligaciones tributarias (art. 34.1.a de la Ley General Tributaria), derecho que luego se concreta en los art. 85 y siguientes; y el de ser informados, al inicio de las actuaciones de comprobación e inspección, sobre la naturaleza y alcance de las mismas, así como de sus derechos y obligaciones en el curso de tales actuaciones (art.34.1.ñ).

${ }^{9}$ La Ley 30/1992 hace otra mención a los asesores al regular los motivos de abstención de las autoridades y del personal al servicio de las Administraciones (art. 28.2.b LRJ).

${ }^{10}$ GONZÁLEZ NAVARRO, F., op. cit., pág. 647-648, que añade que durante el desarrollo de la ac-
} 
Es de alabar que el precepto contemple expresamente y con carácter general la cuestión, ya que ello hace innecesarias las previsiones específicas para determinadas clases de procedimientos, con el consiguiente peligro de creación de regímenes jurídicos cuyas diferencias en muchas ocasiones carecen de justificación, como veremos más adelante.

Asimismo es de alabar la amplitud de contenido del precepto, que confirma el principio antiformalista que rige en la materia. $\mathrm{Ni}$ siquiera es necesario que se trate de un técnico.

Con aplicación a la asistencia jurídica cabe, pues, tanto la autodefensa como la defensa técnica. Lo que ocurre es que normalmente esta última no se refleja en el propio procedimiento, ya que, cuando se trata de alguna actuación escrita, el escrito en cuestión lo redacta el asesor y el interesado simplemente lo firma.

D) Asimismo, conforme al art. 32.2, cualquier persona con capacidad de obrar podrá actuar en representación de otra ante las Administraciones públicas. La actividad de representación no está reservada, pues, a ningún grupo profesional específico. La Orden de 30-04-66 trató de poner limitaciones, pero el Tribunal Supremo las consideró ilegales, rechazando que la presentación de solicitudes ante la Administración estuviera reservada a los gestores administrativos ${ }^{11}$. Por su parte, GONZÁLEZ PÉREZ y GONZÁLEZ NAVARRO aluden a la STS 17-10-83, añadiendo que no puede negarse la posibilidad de ser representante habilitado a otros profesionales (aparte de gestores administrativos, abogados, procuradores y graduados sociales), como son los profesores mercantiles en los procedimientos tributarios, los arquitectos en los urbanísticos y los agentes de la propiedad industrial ante el Registro de la Propiedad Industrial ${ }^{12}$. En consecuencia, el interesado puede otorgar la representación a quien le asesore o le preste asistencia jurídica.

tuación de que se trate (práctica de una prueba, examen del expediente, etc.) el asesor podrá comunicarse con el interesado que le ha presentado como tal, y ello con absoluta libertad, de forma pública o con la reserva que uno y otros consideren necesaria; y asimismo podrá examinar el expediente administrativo si es éste el motivo de la presencia del interesado en la oficina administrativa y solicitar las aclaraciones o explicaciones necesarias. En igual sentido, GONZÁLEZ PÉREZ, J. y GONZÁLEZ NAVARRO, F., Comentarios a la Ley de régimen jurídico de las Administraciones públicas y del procedimiento administrativo común, Madrid, 2007, tomo II, pág. 2205.

11 Sentencias del Tribunal Supremo (en adelante, STS) 29-01-92, referencia Aranzadi (en adelante, Ar.); 27-05-92, Ar. 3736, 19-01-96, Ar.435.

12 Comentarios, cit., tomo I, pág. 956. 
Cabe observar que determinadas normas canalizan a través de la institución de la representación actividades que indudablemente presuponen una actividad de asesoramiento. Piénsese, por ejemplo, en la remisión electrónica de datos (sistema RED) en determinadas actuaciones en el ámbito de la Seguridad Social ${ }^{13}$.

E) Por otra parte, el art. 81 LRJ, al tratar de la práctica de la prueba, dice que en la notificación del inicio de las actuaciones para la realización de las pruebas, se hará constar "la advertencia, en su caso, de que el interesado puede nombrar técnicos para que le asistan". Este precepto ya aparecía en el art. 89.2 de la Ley de Procedimiento de 1958. Aunque la Ley parece estar pensando en lo que genéricamente las normas procesales llaman peritos, no cabe duda que también incluye a los técnicos en Derecho, es decir, a los asesores jurídicos. Piénsese, por ejemplo, en el interrogatorio del interesado en un procedimiento disciplinario.

\section{El asesoramiento en el procedimiento administrativo sancio- nador}

En el ámbito del procedimiento sancionador no existe ninguna especialidad en lo referente al asesoramiento ${ }^{14}$. Por tanto, no se recoge un supuesto derecho específico y peculiar a la asistencia jurídica entre los principios del procedimiento sancionador (art. $135 \mathrm{LRJ}$ ). Y es que el reconocimiento específico resulta innecesario, a la vista de las previsiones generales del art. 85.2 LRJ para todos los procedimientos administrativos.

\section{Naturaleza jurídica de la asistencia jurídica}

De las normas antes citadas cabe deducir que la asistencia jurídica en el procedimiento administrativo - $y$, más en general, el asesoramiento- no constituye una carga, en el sentido de que deba designarse letrado para obtener un determinado beneficio, ya que para la intervención en el procedimiento administrativo no se exige ningún requisito de postulación. Tampoco se trata de un derecho subjetivo de naturaleza prestacional que imponga a la Administración un deber positivo, como el de la designación de abogado por ser preceptiva su intervención, o el carácter gratuito de la asistencia.

13 Orden de 3-04-1995. Se contempla expresamente la posibilidad de intervención, con carácter general, de profesionales colegiados, sin aludir a una profesión específica, canalizándola a través de la representación.

14 Sobre el derecho a la asistencia jurídica en el procedimiento administrativo sancionador, vid. ALARCÓN SOTOMAYOR, A.: El procedimiento administrativo sancionador y los derechos fundamentales, Thomson-Civitas, Gizur Menor, 2007, pág. 245 ss. 
Por el contrario, se trata de un derecho subjetivo frente al cual la Administración tiene una mera obligación de abstención y respeto, en definitiva, de no hacer o soportar.

Tratándose de un derecho subjetivo, ¿cabe calificarlo como derecho fundamental? Algunos autores entienden que sí, cuando se trata de un procedimiento administrativo sancionador ${ }^{15}$.

Sin embargo, no cabe hablar de un derecho fundamental a la asistencia jurídica, ni siquiera en el ámbito sancionador, salvo supuestos muy específicos, que luego veremos ${ }^{16}$. Por tanto, su posible lesión constituiría una infracción de la legislación ordinaria, y no la violación de un derecho constitucional susceptible de amparo (art. 53.2 de la Constitución).

\section{La lesión del derecho a la asistencia jurídica}

En cualquier caso, la eventual lesión del derecho a asesoramiento y a la asistencia jurídica constituye un vicio. La Ley de régimen jurídico de las Administraciones Públicas y del procedimiento administrativo común no dice nada sobre esto con carácter general, ni en el ámbito sancionador ni en el ordinario.

Por tanto, la infracción del derecho a la asistencia jurídica en cualquiera de sus formas en el procedimiento administrativo se rige por las reglas generales. En consecuencia, es muy difícil que dé lugar a un vicio de nulidad de pleno derecho, ya que no encaja en ninguno de los supuestos del art. 62 LRJ. Y sólo constituirá un vicio de anulabilidad cuando se haya producido indefensión material, constituyendo en los demás supuestos una irregularidad no invalidante (art. 63). En particular, no cabe invocar indefensión por falta de asistencia técnica o por el hecho de que la Administración no haya notificado al interesado la posibilidad de designación de defensor técnico ${ }^{17}$.

\footnotetext{
${ }^{15}$ Según TRAYTER, se causa indefensión y se vulnera el art. 24 CE cuando se impida al expedientado la posibilidad de asesorarse durante la tramitación del expediente (TRAYTER JIMÉNEZ, J.M., El procedimiento administrativo sancionador, en Fusticia Administrativa, Revista de Derecho Administrativo, número extraordinario, 2001, pág. 85).

${ }^{16}$ GARCÍA GÓMEZ DE MERCADO dice que "no es de aplicación a las sanciones administrativas el derecho a la asistencia letrada, limitado a los procesos penales por delito" (Sanciones administrativas, Ed. Comares, Granada, 2008, pág. 162). Sin embargo, una cosa es que no constituya un derecho fundamental y otra que no constituya un derecho, que sí lo es, porque está recogido con carácter general por la Ley de régimen jurídico de las Administraciones Públicas y del procedimiento administrativo común.

${ }^{17}$ Puede causar indefensión, por ejemplo, la prohibición expresa por la Administración a la intervención
} 
Desde otro punto de vista, la intervención de letrado en la vía administrativa no puede servir para que la Administración se excuse de sus errores. Ante una interposición extemporánea de un recurso como consecuencia de un erróneo pie de recurso, el Tribunal Constitucional ha rechazado la alegación de la Administración según la cual el interesado contaba con asistencia letrada, ya que la protección de los administrados frente a las irregularidades administrativas no puede hacerse depender de la presencia o no de Letrado, ni puede hacerse de peor condición a aquellos asistidos por dirección técnica letrada (STC 193/1992, 194/1992 y 214/02).

\section{5. ¿Está reservada la asistencia jurídica en el procedimiento ad- ministrativo a los abogados?}

En principio el abogado es el profesional más adecuado para la asistencia jurídica en el procedimiento administrativo. Pero nada impide que el asesoramiento jurídico en el procedimiento administrativo pueda realizarse por otras personas. Piénsese en profesores de Derecho, en entidades de defensa de derechos e intereses, etc. Así, el art. 23.1 del Texto Refundido de la Ley de Consumidores y Usuarios de 16-11-2007 contempla que las asociaciones de consumidores y usuarios tengan como finalidad la defensa de los derechos e intereses legítimos de los consumidores. Según el art. 37.c), las asociaciones de consumidores y usuarios tendrán como finalidad, entre otras, representar a sus asociados y ejercer las correspondientes acciones en defensa de los mismos. Supuestos similares se contemplan en la legislación de extranjería y asilo.

En este sentido existe una importante jurisprudencia penal emanada en relación con el delito de intrusismo profesional. El Tribunal Supremo ha dejado claro que el asesoramiento en Derecho en el procedimiento administrativo no está reservado al abogado, pues esta profesión colegiada tiene esa reserva en la vía judicial, pero no en la vía administrativa. En general las sentencias en cuestión parten de la base de que la actuación del abogado se limita a la que se realiza en juicio, con base en el art. 24.2 CE, quedando excluidas de su monopolio las realizadas en el ámbito administrativo. De hecho, los casos contemplados suelen ser de personas que se atribuyen la condición de abogados y que se ofrecen a realizar gestiones ante la Administración (tramitación de permisos para extranjeros, obtención de permiso de conducción, etc) ${ }^{18}$.

de asesor en el procedimiento administrativo. La Sentencia de la Audiencia Nacional de 27-01-2000 (Ar. 26) (citada por ALARCÓN, cit., pág. 253) rechaza que exista un defecto formal causante de indefensión por el hecho de que el interesado en comparecencia pidiera que se le designara una abogado de oficio, "petición que resultaba improcedente, pues en el procedimiento sancionador no es necesaria la intervención de letrado".

${ }^{18}$ En la STS 2-04-79 (Ar. 1546) se contempla el caso de un procesado que realizó actos tales como 


\section{6. ¿Debe contemplarse expresamente la intervención de aboga- do en el procedimiento administrativo?}

Creo que no debe contemplarse expresamente la intervención de abogado en el procedimiento administrativo, bastando las reglas generales contempladas en la Ley de régimen jurídico de las Administraciones públicas y del procedimiento administrativo común.

No cabe trasladar automáticamente las previsiones de la legislación procesal a la vía administrativa en lo que se refiere a la intervención de letrado. El procedimiento administrativo no puede reducirse a ser considerado una mera vía previa a la judicial, no es una mera actividad preprocesal, sino que tiene una sustantividad propia.

Existe otro dato importante. Normalmente los interesados no pueden acceder por sí mismos a la vía judicial, sino que necesitan unos requisitos de pos-

redactar un recurso de alzada, entendiendo el tribunal que no existe delito de intrusismo porque no era precisa la intervención de abogado, "por no tratarse de una contienda jurídica, sino meramente administrativa". La STS 29-09-06 (Ar. 6400) rechaza que en el asunto que resolvía se hubiera producido un delito de intrusismo, porque no se habían realizado "actos propios de ejercicio de la profesión de abogado". En el caso, la interesada se atribuía la condición de abogada especializada en materia de extranjería -a pesar de carecer de tal título- y asesoraba a los clientes para obtener la documentación necesaria. La sentencia pone de relieve que a pesar del amplio contenido del art. 9.1 del Estatuto General de la Abogacía (aprobado por Real Decreto 658/01 de 22 de junio) que alude a los que "se dedican de forma profesional al asesoramiento, concordia y defensa de los intereses jurídicos ajenos, públicos o privados", el asesoramiento realizado por la interesada "no constituye un acto exclusivo de la profesión de abogado", añadiendo que "el objeto del mismo se realizaba en el plano meramente administrativo, y nunca en el judicial" (a la dirección y defensa de las partes en toda clase de procesos se refiere el art. 542 de la Ley orgánica del Poder Judicial, en adelante, LOPJ). A ello añade que la "determinación de funciones deberá ser realizada desde una perspectiva objetiva de valoración social", por lo que "debe tenerse presente que cualquier ciudadano es susceptible de recibir a diario consejos (médicos, sanitarios, de rehabilitación, construcción o reparación de aparatos de todo tipo o de viviendas) que propiamente solamente deberían darlos profesionales cualificados, y no por ello alcanza tal hecho el desvalor social capaz de merecer una sanción penal". Y añade que "en el plano jurídico, la implicación o proyección de la persona y de sus múltiples facetas en el mundo del derecho le hace susceptible de recibir consejos de tal orden en muy diversos planos (mercantil, bancario, bursátil; tributario, laboral y relacionado con la Seguridad Social), sin que tenga que llegar a la tipicidad penal que debe quedar reservada para cuando lo que se ejecuta pertenece en exclusiva a una determinada profesión". A continuación, la sentencia pone de relieve que la legislación de extranjería no exige la dirección letrada para la tramitación administrativa de determinados asuntos. Y lo mismo cabe decir -continúa la sentencia- con respecto a la normativa que rige la convalidación, obtención o renovación de los permisos para la conducción de vehículos de motor. Por su parte, la STS 12-04-10 (Ar. 5551) menciona expresamente a la anterior, añadiendo que ninguna relevancia penal tiene la previa actividad de asesoramiento puramente administrativo, que no invade las funciones propias del ejercicio profesional de la abogacía. 
tulación: la designación de abogado de oficio deriva de esa necesidad. Esos requisitos, en cambio, no existen en la vía administrativa, por lo que falta el fundamento de su posible existencia.

Por otra parte, contemplar expresamente la intervención de abogado en el procedimiento administrativo supondría olvidar la existencia de profesionales especializados, como los graduados sociales, gestores administrativos, etc ${ }^{19}$.

Así, por lo que se refiere a los graduados sociales el art. 1 de la Orden de 28 de agosto de 1970 dice que "a los graduados sociales, en su condición de técnicos en materias sociales y laborales, les corresponden las funciones de estudio, asesoramiento, representación y gestión, sin necesidad de apoderamiento especial, en los casos permitidos por la Ley de Procedimiento Administrativo en todos cuantos asuntos laborales y sociales les fueran encomendados por o ante el Estado, entidades paraestatales, corporaciones locales, la Seguridad Social, la Organización sindical, entidades, empresas y particulares" 20 . Sobre esta base, ninguna duda existe acerca de la posibilidad de asesorar en materia laboral y de Seguridad Social ${ }^{21}$.

La STS 21-11-98 (Ar. 9964) afirma que la "técnica jurídica" está reservada a la abogacía, pero reconoce que los graduados sociales ejercen técnica jurídica en el campo limitado al concreto ámbito sociolaboral, lo que supone "conocimientos parciales de Derecho".

Por lo que se refiere a los gestores administrativos, el art. 1 del Decreto $424 / 1963$ dice que son profesionales que se dedican de modo habitual y con carácter de profesionalidad y percepción de honorarios a promover, solicitar y realizar toda clase de trámites que no requieran la aplicación de la técnica jurídica reservada a la abogacía, relativos a aquellos asuntos que en interés de personas naturales o jurídicas, y a solicitud de ellas, se sigan ante cualquier órgano de la Administración Pública, informando a sus clientes del estado y vi-

${ }^{19}$ Ver STS 5-05-88 (Ar. 3720) sobre ámbito de competencias de graduados sociales y gestores administrativos, aludiendo al Decreto $1531 / 65$ de 3 de junio, que delimita tales competencias.

${ }^{20}$ Esta norma ha sido declarada en vigor por el Real Decreto 1415/2006, de 1 de diciembre, por el que se aprueban los Estatutos Generales de los Colegios Oficiales de Graduados Sociales (Disposición Derogatoria única.2).

${ }^{21}$ La profesión de graduado social es una profesión jurídica (TARRAGA POVEDA, J., La representación y defensa en juicio por graduado social, Ed. Laborum, Murcia, 2001, pág. 76, recogiendo opiniones de otros autores). El voto particular del magistrado Mendizábal Allende en la STC 2/1995 de 10 de enero afirma que los graduados sociales no son juristas, ya que los estudios que dan lugar a su título no pretenden una formación jurídica integral, pero reconoce que desarrollan una actividad asesora y asistencial. 
cisitudes del procedimiento por el que se desarrollan. Y su art. 2 añade que los gestores administrativos actúan ante los órganos de las Administraciones públicas en calidad de representantes al amparo de dispuesto en el artículo 32.2 de la Ley 30/1992. Lo cual les excluye de la actividad de asesoramiento jurídico, aunque indudablemente en muchas ocasiones el deslinde será muy difícil de realizar.

Por su parte, el art. 2.2 del Real Decreto 278/00 de 25 de febrero, que aprueba los estatutos del Colegio Oficial de Agentes de la Propiedad Industrial establece que las funciones propias de los agentes de la propiedad industrial son las de "ofrecer y prestar habitualmente sus servicios ... para aconsejar, asistir o representar a terceros para la obtención de registros en las diversas modalidades de la propiedad industrial y la defensa de los derechos derivados de los mismos ante la Oficina Española de Patentes y Marcas".

Por lo que se refiere a los procuradores, por de pronto es claro que nada impide su intervención como representantes de los ciudadanos ante la Administración, dada la amplitud de la previsión del art. 32.2 LRJ, a pesar de que la LOPJ se refiere a ellos solo en el ámbito procesal.

El Real Decreto 1373/2003 de 7 de noviembre, que aprueba el arancel de derechos de los procuradores, en su art. 76, reconoce que el procurador puede realizar actuaciones ante las Administraciones públicas, indicando que en todos aquellos recursos y reclamaciones que se formulen ante cualquier órgano de las Administraciones públicas, el procurador percibirá sus derechos con arreglo a lo dispuesto en el art. 1, con una reducción del 50 por ciento.

Por otra parte, el art. 3 contempla la posibilidad de percepciones no arancelarias, al indicar que "este arancel regula los derechos devengados por los procuradores en toda clase de asuntos judiciales y ante las Administraciones públicas, y quedan excluidos los que correspondan al procurador por los demás trabajos y gestiones que practique en función de lo dispuesto en los artículos 1.709 y 1.544 del Código Civil, y demás normas de aplicación.

Ahora bien, la STS 29-01-04 (Aranz. 2183), dictada en un recurso relativo a las atribuciones de los procuradores, les niega funciones de defensa: "la facultad de ordenar en el ámbito de su competencia la actividad profesional de los colegiados, que el artículo 5 apartado i) de la Ley de Colegios Profesionales de 13 de febrero de 1974 atribuye a éstos, ha de ejercerse dentro del ámbito exclusivo de la función que el legislador atribuye a la profesión; y siendo ello así, ha de recordarse que conforme al artículo 438 LOPJ corresponde exclusiva- 
mente a los procuradores la representación de las partes en todo tipo de procesos, salvo cuando la Ley autorice otra cosa, por lo que existe una clara extralimitación en la regulación que en el Estatuto impugnado se contiene en el apartado 3 del artículo $3^{\circ}$ impugnado, al atribuir al procurador la defensa del cliente cuando no esté reservada por Ley a otras profesiones y sin que dicha salvedad legal, no prevista en la legislación vigente, tenga relevancia alguna a efectos de apreciar la clara extralimitación que en dicho precepto se contiene al invadir, con ocasión de la definición del procurador, el ámbito competencial que el artículo 436 de la citada Ley Orgánica confiere al abogado a quien atribuye, en exclusiva, la dirección y defensa de las partes en toda clase de procesos o el asesoramiento y consejo jurídico, sin que pueda aceptarse la forzada interpretación restrictiva que el Abogado del Estado da al término «defensa» que usa el precepto recurrido como limitado a actuaciones procesales incardinadas dentro de las facultades de representación, porque una cosa es la auténtica representación profesional que corresponde al procurador y otra la defensa del mismo y el asesoramiento que está atribuida en exclusiva al abogado por el artículo 436 de la Ley Orgánica del Poder Judicial. Todo lo cual impone la declaración de nulidad del precepto recurrido en cuanto infringe el principio de reserva de Ley en la regulación de la profesión de procurador establecido en el artículo 36 de la Constitución en relación con lo dispuesto en el artículo 5.i) de la Ley reguladora de los Colegios Profesionales."

Parece evidente que, a pesar de lo que razona la sentencia, nada impide que el procurador ejerza funciones de asesoramiento en el procedimiento administrativo, a la vista de lo dispuesto en el art. 85.2 de la Ley de régimen jurídico de las Administraciones públicas y del procedimiento administrativo común.

El Real Decreto 1837/2008 de 8 de noviembre incorpora al ordenamiento jurídico español varias Directivas europeas relativas al reconocimiento de cualificaciones profesionales, así como a determinados aspectos del ejercicio de la profesión de abogado ${ }^{22}$. Según este Real Decreto, las profesiones cuyo ejercicio exige un conocimiento preciso del Derecho positivo español y en las que en el desempeño de sus actividades es un elemento esencial y constante emitir dictámenes, consejos o asistencia sobre el Derecho positivo a efectos de lo dispuesto en el art. 22.3 (necesidad de un periodo de prácticas o de una prueba de aptitud) son las siguientes: abogado, actuario de seguros, agente de la propiedad industrial, auditor de cuentas, detective privado, gestor administrativo,

\footnotetext{
${ }^{22}$ Este Real Decreto derogó al antes citado Real Decreto 1665/1991, de 25 de octubre, sobre reconocimiento de títulos académicos y profesionales en la CEE.
} 
graduado social, graduado social diplomado, diplomado en relaciones laborales, habilitado de clases pasivas, procurador. A la vista de este precepto, resulta indudable que todos estos profesionales pueden asesorar a los interesados en el procedimiento administrativo.

Además, en ocasiones puede estar más justificada la intervención de otros especialistas: así, en una expropiación puede ser más importante la asistencia de un arquitecto o de un ingeniero que la de un abogado ${ }^{23}$.

\section{LA PREVISIÓN DE LA INTERVENGIÓN DE ASESOR EN NORMAS ESPECÍFICAS}

Existen una serie de normas específicas que contemplan expresamente la intervención de abogado o de otro asesor en el procedimiento administrativo. En general se refieren a procedimientos administrativos sancionadores.

\section{Las previsiones en la legislación penitenciaria}

Este es un supuesto importante, porque ha dado lugar a una amplia jurisprudencia del Tribunal Constitucional ${ }^{24}$.

El vigente Reglamento Penitenciario, aprobado por Real Decreto 190/1996 de 9 de febrero, regula la tramitación del procedimiento sancionador, estableciendo que, ante el pliego de cargos, uno de los derechos del interesado interno cuya conducta sea presuntamente constitutiva de falta disciplinaria es el de formular pliego de descargos por escrito o para alegar verbalmente (art. 242.2.h), debiendo indicársele expresamente que el interno puede asesorarse

\footnotetext{
${ }^{23}$ Cabe hacer aquí otra consideración en cuanto al intento de apoderamiento de facultades por parte de determinadas profesiones. Tradicionalmente se venía utilizando la vía reglamentaria, al aprobar los estatutos de las distintas profesiones. Pues bien, la STS 7-02-1979 (Ar. 294) (ponente, Ángel Martín del Burgo) hace una dura crítica de esta situación. Ante un conflicto interprofesional entre los gestores administrativos y los graduados sociales, acerca de las actividades propias de cada profesión, dice la sentencia que "nada de insólito tiene el que se planteen problemas como el de autos, ya que el ordenamiento de este mundo de los profesionales ha surgido, y sigue de la misma forma, en virtud de concepciones unilaterales y sectoriales, sin la menor coherencia, lo que permite el otorgamiento de atribuciones, como consecuencia de gestaciones coyunturales, o momentos de fortuna, tan proclives a poner en marcha el espíritu expansivo de los distintos Cuerpos, no siempre contenido como debería serlo, por la manera fragmentaria y dispersa en que este Ordenamiento se va elaborando, y hasta por el desigual rango de las normas que lo integran". Actualmente se opta por normas con fuerza de Ley, pero la crítica contenida en esta sentencia sigue plenamente vigente.

${ }^{24}$ Sobre ello, vid., con gran detalle, ALARCÓN SOTOMAYOR, A., cit., pág. 255 ss.
} 
por letrado, funcionario o por cualquier persona que designe durante la tramitación del expediente y para la redacción del pliego de descargos (letra i), así como de la posibilidad de asistirse de un funcionario o interno (letra j) ${ }^{25}$.

Como hemos dicho, existe una abundante jurisprudencia constitucional sobre la materia. Por de pronto, las garantías procesales establecidas en el art. 24.2 CE son aplicables no sólo en el proceso penal, sino también en los procedimientos administrativos sancionadores con las matizaciones que resultan de su propia naturaleza, en cuanto que en ambos casos se ejerce la potestad punitiva del Estado (STC 18/1981, 2/1987, 2/1990, 145/1993, 297/1993, 97/1995, 143/1995, 195/1995, 127/1996, 128/1996, 83/1997, 104/02, $316 / 06,42 / 08)$. No se trata de una traslación literal de las garantías del proceso penal al procedimiento administrativo sancionador, dadas las diferencias entre uno y otro, sino de la aplicación de aquellas que resulten compatibles con la naturaleza del procedimiento sancionador (STC 104/02).

Tratándose de sanciones disciplinarias impuestas a internos penitenciarios, este conjunto de garantías se aplica con especial rigor, al considerar que la sanción supone una grave limitación a la ya restringida libertad inherente al cumplimiento de una pena (STC 74/1985, 2/1987, 297/1993, 97/1995, 128/1996, etc.). Las peculiaridades del internamiento en un establecimiento penitenciario no pueden implicar que «la justicia se detenga en la puerta de las prisiones» (STC 2/1987, 297/1993, 97/1995, 127/1996, 128/1996. 157/00, 91/04 y STEDH Campbell y Fell, de 28 de junio de 1984) (STC 83/97).

No obstante, no se trata de un derecho pleno a la asistencia de letrado que se extienda a su comparecencia personal junto al interno ante los órganos disciplinarios. Lo que la Constitución garantiza en este ámbito es la posibilidad de contar con un asesoramiento jurídico suficiente, por lo que es su obstaculización o impedimento injustificado por parte de la Administración lo que constituye la lesión del derecho de defensa (STC 104/03).

$\mathrm{El}$ asesoramiento puede ser realizado por cualquier persona que el interno designe, siempre que en este caso la solicitud de asesoramiento, en cuanto suponga la comunicación con una tercera persona, sea compatible con las exigencias de seguridad, tratamiento y buen orden del establecimiento que legí-

\footnotetext{
${ }^{25}$ El anterior Reglamento Penitenciario de 1981 contemplaba en el procedimiento disciplinario sancionador el trámite del pliego de cargos, en el que, conforme al art. 130.1.e), debía hacerse constar "la posibilidad de asesorarse durante la tramitación del expediente". Como puede observarse, se hablaba, con gran amplitud, de un asesor, sin mayor especificación.
} 
timamente deben adoptar los responsables del centro penitenciario (STC 104/03, 91/04, 42/08, 71/08 y 10/09).

$\mathrm{Al}$ reconocer expresamente la legislación penitenciaria la posibilidad de que los internos soliciten asesoramiento durante la tramitación de los expedientes disciplinarios, la pasividad o el silencio de la Administración ante una solicitud de este tipo realizada en tiempo y forma ante el órgano competente puede significar la lesión del art. 24.2 CE si supone la privación definitiva de la oportunidad de recibir una asistencia necesaria y eficaz para la preparación de su defensa. Es decir, sólo podrá apreciarse vulneración del derecho de defensa si la que efectiva y concretamente se ha ejercitado en el proceso se manifiesta incapaz de contribuir satisfactoriamente al examen de las cuestiones jurídicas suscitadas en el mismo, lo cual será determinable, en cada caso concreto, atendiendo a la mayor o menor complejidad del debate procesal y a la cultura y conocimientos jurídicos del comparecido personalmente, deducidos de la forma y nivel técnico con que haya realizado su defensa (STC 104/03, 91/0426).

Las STC 71/08 y 10/09 desestimaron sendos recursos de amparo al constatar que lo denegado no fue en sí mismo el hecho del asesoramiento, sino la forma concreta en que el recurrente propuso su realización -entrevista personal-, y ello porque en tal caso la Administración penitenciaria no impidió al recurrente hacer efectivo su derecho, pues, en última instancia, la decisión administrativa no imposibilitaba que ese asesoramiento hubiera podido efectuarse de cualquier otra forma que no resultara contrario a las razones de seguridad y buen orden, como es el asesoramiento por escrito que expresamente posibilitó el instructor. Además - razonaba el Tribunal-, tampoco resultaba posible apreciar defectos constitucionales de motivación en esta decisión, ya que se fundamentó en que no estaban autorizadas las comunicaciones intermodulares entre internos que no fueran familiares directos, identificando así la existencia de un fin constitucionalmente legítimo justificativo, como son las razones de seguridad y buen orden. En tercer lugar, tampoco el hecho de que finalmente el recurrente no pudiera contar con algún tipo de asesoramiento, que es en lo que se concretaría la indefensión material, podía ser imputado a la Administración, toda vez que, ante la negativa del instructor a acceder a realizar el asesoramiento de la manera solicitada, el recurrente no propuso ninguna otra fórmula alternativa, bien en cuanto a la forma de verificarlo, bien eligiendo un asesor en quien no concurrieran esas específicas circunstancias.

\footnotetext{
${ }^{26}$ Esta última niega que se haya producido la vulneración del derecho a la defensa y a la asistencia jurídica sobre la base de que el propio recluso, según parece, ejercitó una autodefensa bien razonada jurídicamente.
} 
El contenido del derecho fundamental a la asistencia jurídica no implica el reconocimiento del derecho a la asistencia jurídica gratuita durante el procedimiento administrativo (STC 74/1985, 2/1987, 229/1993), lo que no contradice el art. 24.2 CE, pues, como resulta del art. 6.3 del CEDH, tal derecho a la gratuidad de la asistencia letrada sólo existe en los procesos judiciales y, además, no en todos, sino sólo cuando el derecho de defensa y los intereses de la justicia lo requieran (STC 2/87, 229/93, 128/96, 83/97, 104/03, 42/08). Aunque comprende el derecho del interno a asesorarse por Letrado de su elección, pese a que no sea preceptiva su intervención, sin embargo, tanto en la fase administrativa como en la fase del posterior recurso ante el Juzgado de Vigilancia Penitenciaria no forma parte de su contenido el derecho a la designación de letrado del turno de oficio (STC 9/1997, de 14 de enero, FJ 3; AATC 145/1999, de 7 de junio; 92/2003, de 24 de marzo). No puede estimarse vulnerado su derecho a la asistencia letrada por no haber contado con asistencia letrada gratuita durante la tramitación del expediente disciplinario, ya que este derecho en los procedimientos de imposición de sanciones a los internos, tanto en su fase ante la Administración penitenciaria como ante el Juzgado de Vigilancia Penitenciaria, no implica la designación de abogado del turno de oficio (STG 42/08).

¿Cuál es el fundamento de ese reconocimiento del derecho a la defensa y a la asistencia jurídica en los procedimientos disciplinarios abiertos a los reclusos como un derecho fundamental? La jurisprudencia constitucional pone el acento en que "la sanción supone una grave limitación a la ya restringida libertad inherente al cumplimiento de una pena", ya que la tramitación del procedimiento puede lugar a una restricción aún mayor de su libertad. Sin embargo, creo que el fundamento de esta especial garantía se encuentra en la especial situación en que se encuentra el recluso: éste se encuentra privado de libertad y tiene restringido su derecho a la comunicación con terceros, lo que supone una seria limitación a sus garantías procedimentales, que en otras circunstancias no tendría lugar. Ello hace que el derecho a asesorarse por parte del recluso no suponga una simple obligación de abstenerse por parte de la Administración penitenciaria, sino que incluye la obligación positiva de facilitar el contacto ${ }^{27}$.

Como consecuencia, cabe hacer las siguientes consideraciones. Por de pronto, es claro que esta consideración como derecho fundamental no puede trasladarse sin más a cualquier otro procedimiento sancionador, como reconoce el propio Tribunal Constitucional. De hecho, tiene un carácter excepcional.

${ }^{27}$ No obstante, esta opinión tiene un punto débil: si la privación de libertad fuera lo relevante, estas garantías deberían trasladarse a todos los procedimientos administrativos en los que estuvieran interesados los reclusos. 
En segundo lugar, hay que tener en cuenta la posición del Tribunal Constitucional, como garante de los derechos fundamentales a través del recurso de amparo. Desde esta perspectiva, la doctrina del Tribunal Constitucional se basa en la protección del derecho fundamental a la defensa y a la asistencia jurídica, que es bastante más estricto que el derecho a recibir asesoramiento en el procedimiento sancionador penitenciario. Parece que la doctrina del Tribunal Constitucional no puede extenderse a otro tipo de asesoramiento distinto a la asistencia jurídica.

Cabe plantear la cuestión de si el recluso tendría ese derecho incluso aunque no estuviera normativamente previsto. También cabe la duda de si esta garantía puede excluirse expresamente. Dicho con otras palabras, la cuestión es si se trata de un derecho que deriva directamente de la Constitución o de la norma que lo establece. El Tribunal Constitucional parece entender lo primero, precisamente por el fundamento en el que se basa (el interesado se encuentra privado de libertad). Y si esto es así, ello formaría parte del contenido esencial del derecho, que no puede ser recortado, y que debería regularse por una norma de superior rango (art. $53 \mathrm{CE}$ ). Lo cierto, sin embargo, que este problema no es tal, dado que la Ley de régimen jurídico de las Administraciones públicas y del procedimiento administrativo común recoge esta posibilidad de asesoramiento.

\section{El régimen disciplinario de las Fuerzas Armadas}

El art. 53.1 de la Ley orgánica 8/98 de 2 de diciembre, sobre régimen disciplinario de las Fuerzas Armadas dice, con respecto a las faltas graves, que el expedientado podrá contar en todas las actuaciones a que dé lugar este expediente sancionador, con el asesoramiento del abogado o del militar que designe al efecto ${ }^{28}$. No es una novedad de esta Ley, pues ya anteriormente esto mismo se contemplaba en la Ley orgánica 12/85 de 27 de noviembre, de régimen disciplinario de las Fuerzas Armadas.

La contemplación expresa de este derecho puede tener sentido en cuanto que el militar puede ser privado de su libertad en el ámbito administrativo, y en tal sentido la previsión expresa tendría su justificación, tanto en lo que se refiere a las garantías procedimentales de comunicación como a las consecuencias que puedan derivar de la actuación administrativa, sin perjuicio de que en caso de que no exista esa privación o restricción de libertad, el interesado pueda asesorarse por quien decida libremente.

${ }^{28} \mathrm{El}$ art. 64 lo extiende a los expedientes gubernativos por sanciones disciplinarias extraordinarias. 
Sin embargo, esta afirmación tiene sus puntos débiles. Por un lado, las sanciones leves - con respecto a las cuales no existe previsión alguna acerca del asesoramiento- pueden comportar restricciones importantes a la libertad. Por el contrario, varias de las sanciones graves no guardan ninguna relación con la privación de libertad. Lo cual hace pensar que se ha tratado de trasladar a un procedimiento disciplinario las garantías previstas en un procedimiento penal.

Por lo demás, la DF $1^{a}$ de la Ley dice que la Ley de régimen jurídico de las Administraciones públicas y del procedimiento administrativo común será de aplicación subsidiaria en todas las cuestiones de procedimiento y recurso no previstas en la Ley, lo que significa que nada impide el asesoramiento -y en particular, la intervención de letrado- en los procedimientos por faltas leves. Hay que tener en cuenta que, aunque ese procedimiento es predominantemente oral, ello no excluye la escritura, por ejemplo, en materia de recursos.

La STS 17-07-06 (Sala de lo Militar) (Ar. 4494) afirma que en los procedimientos para la imposición de sanciones leves no está prevista la intervención de letrado, pero tampoco excluida, siempre que no resulte incompatible con la finalidad del procedimiento oral y sumario por faltas leves. Lo que ocurre es que en el caso en cuestión el interesado ni se hizo acompañar de profesional de la abogacía que le asistiera en el acto, ni solicitó disponer de asesoramiento pidiendo la suspensión del acto por breve plazo de tiempo para no frustrar la rápida decisión que el caso requería.

Por otra parte, la doctrina opina que no debe entenderse como un derecho a la asistencia letrada concebida como la presencia física de su asesor en todas las actuaciones a que dé lugar el procedimiento: la posibilidad de recibir asesoramiento letrado permite al expedientado redactar sus descargos bajo la dirección de letrado, así como aconsejarse de éste para proponer prueba, pero no presupone la presencia fisica del letrado en todos los trámites del procedimiento ${ }^{29}$.

\section{El régimen disciplinario de la Guardia Civil}

La Ley orgánica 11/91 de 17 de junio, de régimen disciplinario de la Guardia Civil, al igual que ocurre con el régimen disciplinario militar, no contemplaba la asistencia jurídica en los procedimientos por falta leve. Con respecto a ello cabe decir lo mismo que con respecto a los militares.

${ }^{29}$ FERNÁNDEZ SEGADO, F., El nuevo régimen disciplinario militar: reflexiones en torno a la obra "Comentarios a la Ley Disciplinaria de las Fuerzas Armadas”, en Revista Española de Derecho Militar, 76, julio diciembre 2000, pág. 151 . 
Precisamente esta circunstancia ha dado lugar a una amplia jurisprudencia de la Sala de lo Militar del Tribunal Supremo sobre la cuestión. Así, la STS 8-02-99 (Ar. 2574) resolvió un caso de procedimiento oral por falta leve producido durante la vigencia de la Ley orgánica 11/91. La sentencia niega que se haya vulnerado el derecho fundamental de defensa. En primer lugar - dice- la asistencia de letrado no está prevista en el procedimiento sancionador por falta leve, lo que le lleva a decir que tal derecho no existe en este procedimiento, por comparación con lo que se establece para el procedimiento por los demás tipos de faltas.

En segundo lugar, afirma que el trámite de audiencia no constituye una fase de declaración, con posibilidad de contradicción, que precise de la asistencia de Letrado; aunque añade que ello "no impide que el supuesto infractor, que mejor conoce lo que ha hecho, pueda obtener ese asesoramiento previo a la resolución sancionadora, y no menos después al interponer los previstos recursos de alzada". Y concluye que "la norma legal disciplinaria responde a aquellas notas de simplicidad del procedimiento, suficientes garantías, y finalidad esencial de reponer con la mayor brevedad la disciplina quebrantada".

$\mathrm{Al}$ realizar esta matización cabe observar que la sentencia realmente no niega el derecho a la asistencia jurídica, sino el que el interesado pueda reclamar que en una determinada fase del procedimiento oral sea asistido por asesor. En lo cual coincide con la doctrina del Tribunal Constitucional que hemos examinado con relación a los reclusos.

La STS 27-09-2001 (Ar. 8701 de 2002) se dictó como consecuencia de un procedimiento sancionador por faltas graves. Ante la alegación de la falta de asistencia jurídica, la sentencia afirma que no se ha producido indefensión material, porque no existe un paralelismo entre el procedimiento administrativo sancionador y el proceso penal, ya que tal asistencia no es preceptiva, por lo que "el asesoramiento jurídico con que quiera contar el encartado, incumbe ante todo a su propia actividad y diligencia, incluida la formulación de quejas o protestas ante el Instructor por los posibles incumplimientos procedimentales en que se hubiera incurrido en el trámite del expediente, reclamaciones que no consta haberse efectuado".

La STS 3-06-02 (Ar. 5878) se remite a la doctrina de la sentencia antes citada de 8-02-1999, indicando que el procedimiento sumario por falta leve fue diseñado por el legislador con tal naturaleza para responder con rapidez -según el Tribunal Constitucional, la prontitud y la rapidez de la reacción constituyen la razón de ser de los procedimientos disciplinarios- frente a las infracciones de la disciplina militar. 
La STS 9-12-2004 (Ar. 8032) insiste en que en aquel momento no estaba prevista la asistencia jurídica en el procedimiento oral por falta leve: "La naturaleza de las infracciones que en él se investigan, el puro ejercicio del mando que representa la investigación y corrección de estas infracciones, la sencillez de los trámites y su celeridad acorde con los intereses militares que tutela ..., justifican este distinto tratamiento procedimental, sin perjuicio para el derecho de defensa del encartado que, desde luego, puede asesorarse en la forma que estime conveniente, a lo largo del procedimiento hasta la resolución definitiva en vía disciplinaria. La necesidad de restablecer con la rapidez necesaria la disciplina quebrantada y la naturaleza de la relación de mando en que se ejerce esa potestad disciplinaria respecto a dichas faltas leves, necesaria para el correcto funcionamiento de la Institución, representan peculiaridades que matizan la aplicación al procedimiento disciplinario militar por faltas leves de la garantía de defensa y permiten, preservando los valores esenciales de ese derecho fundamental que están en la base del precepto (STG 18/1991), establecer la señalada diferencia, en cuanto a la asistencia letrada al encartado, en relación a los mencionados expedientes disciplinarios y gubernativos".

La STC 74/04 estudia el caso de un procedimiento por falta leve a un miembro de la Guardia Civil en el que no se permitió intervenir a una letrada. La sentencia matiza que las restricciones al ejercicio del derecho de asistencia letrada solo resultan admisibles en la medida en que ese ejercicio resulte incompatible con la finalidad del procedimiento disciplinario. El fundamento del procedimiento oral sumario para la corrección de las infracciones leves se encuentra en la finalidad del rápido restablecimiento de la disciplina militar. En el caso, lo determinante fue que el trámite de audiencia quedó fijado para varios días después, y además la letrada se encontraba en las dependencias oficiales, por lo que su intervención no era incompatible con esa finalidad.

Sobre esta base, cabía entender que cuando la asistencia letrada pudiera producirse sin demora y sin que quedase afectado el pronto restablecimiento de la disciplina, la asistencia de letrado no resultaba incompatible con la especial naturaleza del procedimiento.

En la actualidad, sin embargo, el art. 42.2 de la Ley orgánica 12/07 de 22 de octubre, de régimen disciplinario de la Guardia Civil, contempla la posibilidad de que el interesado cuente, en todas las actuaciones a que dé lugar cualquier procedimiento disciplinario, con el asesoramiento y asistencia de un abogado en ejercicio o de un guardia civil que elija al efecto. De optarse por esta segunda posibilidad, las autoridades y mandos correspondientes facilitarán al designado la asistencia a las comparecencias personales del interesado ante las autoridades disciplinarias o instructoras de los expedientes, y su asesoramiento 
será siempre voluntario, sin que tal designación confiera derecho alguno al resarcimiento por los gastos que pudieran derivarse de su asistencia. Los honorarios del letrado designado serán por cuenta del interesado.

Por tanto, se hace alusión expresa a la garantía también en los procedimientos por faltas leves, lo cual supone una innovación con respecto a la anteriormente vigente Ley orgánica 11/91 de 17 de junio, que no contemplaba la asistencia en los procedimientos por falta leve.

Sin embargo, esta nueva Ley ha suprimido las sanciones privativas de libertad. Por ello, realmente este precepto no tiene mucho sentido, puesto que el derecho a asistencia no necesita requisito alguno, y las leyes generales no imponen limitación alguna. Es prácticamente una copia de lo dispuesto para los internos en un centro penitenciario y para los militares, pero en el presente caso no existe el fundamento que concurre en aquéllos, la privación de libertad y la limitación de las comunicaciones. Por ello, parece que la única justificación de esta norma es la de permitir que a los guardias civiles designados para realizar la asistencia se les facilite la asistencia a las comparecencias personales del interesado ante las autoridades disciplinarias o instructoras de los expedientes ${ }^{30}$.

\section{El régimen disciplinario de la policía nacional}

La Ley orgánica 4/10 de 20 de mayo, de régimen disciplinario del Cuerpo Nacional de Policía, contempla la posibilidad de que el interesado designe abogado o policía nacional que le asesore. Según el art. 19.4, en el momento en que se notifique la apertura de un procedimiento disciplinario, se informará al funcionario sometido a expediente de su derecho a ser asistido, cuando lo considere conveniente para la defensa de sus intereses, por un abogado o por un funcionario del Cuerpo Nacional de Policía licenciado en Derecho.

A este precepto cabe hacer la misma crítica que acabamos de hacer al nuevo régimen de la Guardia Civil: el derecho a asistencia no necesita requisito alguno, y las leyes generales no imponen limitación alguna. Y la única justificación de esta norma es la de permitir que los funcionarios del Cuerpo Nacional de Policía designados para realizar la asistencia tengan derecho a un permiso el día en que aquella se realice por el tiempo necesario para ello, tal como se añade por el art. 19.4.2 de la Ley.

\footnotetext{
${ }^{30}$ No obstante, la Ley se cuida de añadir que la designación no confiere derecho alguno al resarcimiento por los gastos que pudieran derivarse de la asistencia, siendo de cuenta del funcionario contratante los honorarios del abogado.
} 
También es aplicable a los Cuerpos de Policía Local de acuerdo con lo previsto en la legislación orgánica reguladora de las Fuerzas y Cuerpos de Seguridad (DF 6 $6^{\mathrm{a}}$ ), aunque es de suponer que la mención al funcionario del Cuerpo Nacional de Policía licenciado en Derecho debe entenderse hecha a un funcionario del correspondiente Guerpo de Policía Local.

\section{Las previsiones de la Ley Orgánica del Poder Judicial}

La Ley orgánica del Poder Judicial, al regular el régimen disciplinario del personal al servicio del Poder Judicial, contempla la posibilidad de intervención de asesor, distinguiendo según la clase de personal. Así, con respecto a jueces y magistrados, el art. 425.1 LOPJ reconoce que el interesado podrá valerse de abogado desde el inicio del expediente ${ }^{31}$.

Por lo que se refiere a los secretarios judiciales y demás personal al servicio de la administración de justicia, los art. 468.4.f y 535.6, respectivamente, reconocen el derecho a poder actuar en el procedimiento asistidos de letrado o de los representantes sindicales que determinen ${ }^{32}$.

Cabe observar que el contenido de los art. 468 y 535 no data de la regulación inicial de 1985, que nada contemplaba sobre este punto, sino que fueron introducidos muy posteriormente, por la Ley orgánica 19/03 de 23 de diciembre. Puede hablarse así de unas garantías de segunda generación, empeñado el legislador en introducirlas cuando ya existían garantías suficientes en virtud de la aplicación de las reglas generales.

En efecto, tales preceptos son técnicamente muy criticables. En primer, lugar, por aplicación de las reglas generales, resultan innecesarios, ya que en todos estos casos rige la Ley de régimen jurídico de las Administraciones públicas y del procedimiento administrativo común, como se dice expresamente en los propios Reglamentos de desarrollo.

\footnotetext{
${ }^{31}$ Según redacción dada por la Ley orgánica 16/94 de 8 de noviembre. Como apunta ALARCÓN, ello resulta muy llamativo, porque la formación de los jueces parece excluir la indefensión (op. cit., pág. 263). Este precepto no es aplicable cuando se trata de la sanción leve de advertencia.

32 Vid. el Real Decreto 1608/2005, de 30 de diciembre, por el que se aprueba el Reglamento Orgánico del Cuerpo de Secretarios Judiciales; así como el Real Decreto 796/2005, de 1 de julio, por el que se aprueba el Reglamento general de régimen disciplinario del resto del personal al servicio de la Administración de Justicia. Como dice ALARCÓN, resulta paradójico que se reconozca expresamente este derecho a quienes pueden comparecer por sí mismos en un recurso contencioso administrativo sin necesidad de abogado y de procurador (art. 23.3 de la Ley de la Jurisdicción Contencioso Administrativa (op. cit., pág. 263).
} 
Además, al contrario de lo que sucede con los privados de libertad o con los militares, no concurre ninguna circunstancia que haga aconsejable su mención expresa.

Pero es que su mención puede llegar a ser contraproducente. En primer lugar, de interpretarlo en sus términos literales, supondría que el interesado no puede asesorarse por otra persona distinta a las indicadas. Y en segundo lugar, literalmente parece que no podría optar por ambas clases de personas, sino que debería optar por una de ellas, al utilizar la conjunción "o".

Por otra parte, resulta llamativo la equiparación de la asistencia letrada con la de los representantes sindicales, como si fueran equivalentes, cuando es evidente que se trata de una defensa muy diferente, ya que la del letrado en principio debe ser jurídica mientras que la de los representantes sindicales no tiene por qué poner el acento en los aspectos jurídicos.

\section{La legislación reguladora del derecho de asilo y de la condi- ción de refugiado}

La Ley 5/84 de 26 de marzo, reguladora del derecho de asilo y de la condición de refugiado, decía ya en su Preámbulo que "el reclamante (de asilo) puede valerse de abogado, que se nombrará de oficio si lo solicita".

En su desarrollo, el art. 5.4 decía que "el solicitante de asilo será instruido por la autoridad a la que se dirigiera de los derechos que le corresponden de conformidad con esta Ley y, en particular, del derecho a la asistencia de letrado". Posteriormente, tras la reforma de la Ley por la 9/1994 de 19 de mayo, se dio una nueva redacción al art. 4.1, en virtud de lo cual el solicitante de asilo que se encontrara en territorio español "en todo caso tendrá derecho a asistencia letrada, intérprete y atención médica".

Por su parte, el art. 5.2 del Reglamento de la Ley (Real Decreto 203/1995 de 10 de febrero) reitera la obligación de informar del derecho a la asistencia letrada. Y el art. 8.4 insiste en que los solicitantes de asilo que se encuentren en territorio nacional tendrán derecho a asistencia letrada para la formalización de su solicitud y durante todo el procedimiento.

A la vista de esta regulación, cabe hacer una serie de consideraciones. En primer lugar, hay que resaltar que el procedimiento en cuestión no es de naturaleza sancionadora. 
En segundo lugar, recoge un derecho que al día de la fecha viene ya establecido, con carácter más general, en la Ley de régimen jurídico de las Administraciones públicas y del procedimiento administrativo común. Desde esta perspectiva, no se trata de un derecho de naturaleza prestacional, en el sentido de que confiera un poder a un interesado para exigir que los poderes públicos le provean de asistencia letrada, sino de un derecho que impone a los poderes públicos la obligación de no obstaculizarlo. No obstante, induce a cierta confusión el hecho de que se contemple junto con otros derechos que sí tienen un contenido prestacional, como son los de intérprete y atención médica. Por otra parte, esta afirmación ha quedado muy relativizada tras la aprobación de la Ley de Extranjería, como veremos a continuación.

En tercer lugar, cabe observar que la Ley no hacía mención alguna a una asistencia jurídica gratuita. Lo único que decía el Preámbulo es que se le nombrará abogado de oficio si lo solicita. Pero una cosa es la designación de abogado de oficio y otra que la asistencia de ese abogado sea gratuita. No cabe confundir designación de oficio con carácter gratuito de la asistencia.

La expresión "designación de oficio" en estos casos es muy equívoca y no responde a la realidad. La expresión "de oficio" se contrapone a "a petición del interesado", es decir, hace referencia al modo de designación del abogado. En este sentido es contradictorio aludir a una petición (a instancia de interesado) de designación de abogado "de oficio". Solo cabe hablar de designación de abogado de oficio en los casos en que sea preceptiva su intervención y el interesado no lo designe, como ocurre en el proceso penal ${ }^{33}$.

En cuarto lugar, procede hacerse eco de la crítica de BLANQUER a la intervención de abogado en estos $\operatorname{casos}^{34}$. Este autor pone de relieve que la Guía aprobada por ACNUR en 1979 no se refiere a la asistencia letrada en la vía administrativa, sin que tampoco se contemple en la legislación de Francia y Dinamarca. Asimismo recuerda que el apartado 13 de la resolución del Consejo de

33 Vid. GUERRERO FERNÁNDEZ, P., Designación de abogado de oficio y justicia gratuita, en PICÓ JUNOY, J. (dir.), Presente y futuro del proceso civil, Bosch editor, Barcelona, 1998, pág. 203-204. Este autor dice que con la primitiva redacción de la Ley de Enjuiciamiento Civil no se planteaba tal problema, porque el cliente que no conocía a ningún abogado iba al Colegio y le designaban uno, y éste tramitaba o no, según el caso, el beneficio de justicia gratuita: si no tenía derecho a ella, el abogado pasaba sus honorarios; si lo tenía, era gratis (pág. 204). Para el autor, la actual redacción de la Ley de Asistencia Jurídica Gratuita (en adelante, LAJG) incurre en la confusión, y lo mismo el Estatuto General de la Abogacía (en la actualidad, art. 45.1 del vigente) (pág. 205). El autor opina que habría que distinguir dos procedimientos: uno para la designación de abogado de oficio; y otro para el reconocimiento de la asistencia gratuita.

${ }^{34}$ D. BLANQUER, Asilo politico en España. Garantías del extranjero y garantías del interés general, Civitas-Ministerio del Interior, Madrid, 1997, pág. 190 ss. 
la Comunidad Europea de 20 de junio de 1995, sobre garantías mínimas en los procedimientos en materia de solicitud de asilo, dice que los solicitantes de asilo podrán recurrir a un abogado autorizado con arreglo a las disposiciones del Estado miembro de que se trata, o a otro tipo de asesor, que le asista durante el procedimiento. Nótese que esto es lo que ocurre en alguno de los sectores que hemos estudiado, que contemplan el asesoramiento con gran amplitud.

En un plano práctico, BLANQUER pone de relieve que en este tipo de procedimientos prevalecen las cuestiones de tipo probatorio, no las cuestiones jurídicas, de lo que deduce que en estos procedimientos es más importante tener conocimiento y experiencia práctica de los problemas generales que plantea el asilo, que tener preparación jurídica.

En este sentido, parece más adecuado lo dispuesto en el art. 5.5, según el cual el Alto comisionado de (ACNUR) podrá informarse de la situación de los expedientes, estar presente en las audiencias al solicitante y presentar informes, verbales o escritos, por sí o por representante apoderado al efecto, ante el Ministro del Interior; e igualmente "se permitirá a las asociaciones legalmente reconocidas que entre sus objetivos tengan el asesoramiento y ayuda al refugiado y la presentación de informes escritos ante el Ministro del Interior". Por su parte, la Disposición Adicional $3^{\mathrm{a}}$ del Reglamento de la Ley contempla la posibilidad de nombrar abogados colaboradores de ACNUR en el procedimiento.

La Ley de Extranjería 4/2000 de 11 de enero introdujo una modificación sustancial en lo referente a la intervención de abogado, como veremos a continuación ${ }^{35}$.

\section{LA PREVISIÓN EXPRESA DE LA INTERVENGIÓN DE LE- TRADO CON EL ACENTO EN LA ASISTENCIA JURÍDICA GRATUITA}

\section{La Ley de Asistencia Jurídica Gratuita}

La Ley 7/1996 de 10 de enero, de asistencia jurídica gratuita, regula este derecho en desarrollo de lo dispuesto en el art. $119 \mathrm{CE}$, que, como vimos, iba referido a la vía jurisdiccional. Por tanto, la asistencia fuera de esta vía se con-

\footnotetext{
35 Por otra parte, hay que tener en cuenta que en la actualidad la Ley 5/84 de 26 de marzo, reguladora del derecho de asilo y de la condición de refugiado, ha sido sustituida por la Ley 12/2009, de 30 de octubre, reguladora del derecho de asilo y de la protección subsidiaria. Entre las novedades que introduce esta Ley cabe destacar, en lo que se refiere a nuestro tema, que la asistencia jurídica será preceptiva cuando las solicitudes de protección internacional sean presentadas en puestos fronterizos (art. 16.2).
} 
templa de una manera tangencial y complementaria. Ello nos lleva a una primera conclusión, y es que el posible derecho a la asistencia jurídica gratuita en la vía administrativa no deriva de la Constitución, sino de la Ley. Por tanto, en principio, no cabe invocar un supuesto derecho fundamental o constitucional a la asistencia jurídica gratuita en la vía administrativa.

Así pues, este derecho puede ser reconocido por una norma de rango infraconstitucional, pero tiene un carácter excepcional. Es muy significativo en este sentido que, según el art. 1.2 LAJG, las disposiciones de la Ley serán de aplicación general en todo tipo de procesos judiciales, incluidos los recursos de amparo constitucional, así como el asesoramiento previo al proceso contemplado en el art. 6.1.

Según este último precepto, el derecho a la asistencia jurídica gratuita comprende, entre otras, la prestación de "asesoramiento y orientación gratuitos previos al proceso a quienes pretendan reclamar la tutela judicial de sus derechos e intereses, cuando tengan por objeto evitar el conflicto procesal, o analizar la viabilidad de su pretensión”.

Algunos autores han entendido que ello podría fundamentar un derecho a una asistencia jurídica gratuita en la vía administrativa ${ }^{36}$. Sin embargo, no es posible compartir esta opinión. Asesorar y orientar no equivalen a una defensa técnica, sino que es un estadio anterior. Asesorar y orientar es indicar al interesado los pros y los contras de una actuación, dar consejos de cómo actuar. Pero no llega al extremo de llegar a redactar, por ejemplo, un recurso administrativo. Es muy significativo el dato de los fines a los que se dirige: por un lado, el de analizar la viabilidad de la pretensión, que -hay que insistir- constituye un estadio previo; por otro, el de evitar el conflicto procesal, siendo así que la tramitación de un procedimiento administrativo goza de plena autonomía con respecto a la vía procesal, y su fin no es el de evitar un conflicto procesal, sino garantizar el acierto de la actuación administrativa y los derechos de los ciudadanos.

\footnotetext{
${ }^{36}$ REQUERO IBÁÑEZ, J.L., La justicia gratuita en el orden contencioso administrativo, en VVAA, Justicia gratuita, en Cuadernos de Derecho Fudicial, vol. 24, 1995. pág. 270. A este autor le llama la atención el que no se contemple la garantía de la asistencia jurídica gratuita en el ámbito administrativo, porque la complejidad técnica es igual o, si cabe, mayor que en el procedimiento judicial" (op. cit., pág. 267). Pero según este argumento, basado en la complejidad, habría que reconocer el derecho a la asistencia jurídica gratuita en las relaciones civiles, por ejemplo, a la hora de redactar un contrato entre particulares o de constituir una sociedad mercantil. La opinión del autor presupone que el procedimiento administrativo es un mero antecedente o presupuesto de la vía judicial, idea que no comparto, como se expone a continuación.
} 
Vista la dicción del art. 6.1 LAJG, ni siquiera puede entenderse que la asistencia jurídica gratuita tiene cabida en los supuestos del art. 88 LRJ, de terminación convencional del procedimiento.

Sin embargo, la propia LAJG recoge unas ampliaciones referidas a la vía administrativa, que indudablemente tienen un carácter excepcional. Según su art. 2.f), en su inicial versión, "en el orden contencioso administrativo así como en la vía administrativa previa, los ciudadanos extranjeros que acrediten insuficiencia de recursos para litigar, aun cuando no residan legalmente en territorio español, tendrán derecho a la asistencia letrada y a la defensa y representación gratuita en todos aquellos procesos relativos a su solicitud de asilo"37.

Posteriormente, el anterior precepto ha sido sustituido por el art. 2.e) LAJG, según el cual "en el orden contencioso administrativo así como en la vía administrativa previa, los ciudadanos extranjeros que acrediten insuficiencia de recursos para litigar tendrán derecho a la asistencia letrada y a la defensa y representación gratuita en los procedimientos que puedan llevar a la denegación de su entrada en España, a su devolución o expulsión del territorio español, y en todos los procedimientos en materia de asilo". La modificación tenía por objeto adecuar la LAJG a la doctrina del Tribunal Constitucional, para introducir expresamente la referencia a los extranjeros que no acuden a la vía del asilo, sino a la ordinaria, que hasta entonces se había regido por la Ley específica de extranjería.

Continúa la criticable la alusión a la vía administrativa previa, pues la trata como un simple presupuesto previo al acceso a la vía judicial, como si la vía administrativa siempre hubiera de desembocar en la judicial, presuponiendo una continuidad que no tiene por qué existir. La vía administrativa y la vía judicial son independientes y autónomas. La LAJG incurre en un evidente error de concepto: puede notarse que cuando la LRJ habla de una reclamación previa (art. 120 y siguientes) es porque el interesado ya ha decidido acudir a la vía judicial, y con la reclamación se da la posibilidad a la Administración de reconsiderar su actuación. En ello mismo está pensando la LAJG, a pesar de que el procedimiento administrativo cumple unas funciones más complejas que la de constituir un mero requisito para el acceso a la vía judicial.

\footnotetext{
${ }^{37} \mathrm{El}$ precepto era técnicamente bastante deficiente. Por un lado, parecía considerar que el procedimiento administrativo en materia de asilo era una mera vía administrativa previa a la judicial, siendo así que tiene una especificidad propia. Por otro lado, el derecho a la representación y defensa se limitaba a los procesos, según el propio precepto, olvidándose de la vía administrativa previa.
} 
Por otro lado, según una interpretación literal del art. 2.e) LAJG, los extranjeros también tendrían derecho a procurador en la vía administrativa, lo que no parece correcto, ya que por la vía de la asistencia jurídica gratuita se estaría introduciendo un nuevo derecho en esta clase de procedimientos administrativos que no existe en el resto de los procedimientos administrativos, y ni tan siquiera en algunos procesos judiciales, como ocurre en el caso de los procesos seguidos ante los Juzgados de lo Contencioso Administrativo (art. 23 de la Ley de la Jurisdicción Contencioso Administrativa). Hay que recordar a este respecto que solo se tiene derecho a la representación gratuita de procurador cuando su intervención sea legalmente preceptiva (art. 6.3 LAJG).

Por otra parte, la asistencia jurídica gratuita en la vía administrativa sólo se contempla en los procedimientos relativos a la denegación de entrada en España, a la devolución, a la expulsión del territorio español, así como en materia de asilo. En los demás supuestos (por ejemplo, solicitudes de autorización de trabajo o de residencia) rigen las reglas generales.

\section{La legislación de extranjería}

El art. 30.2 de la Ley orgánica 7/85 de 1 de julio, sobre derechos y libertades de los extranjeros en España, establecía que, en determinados supuestos, cuando de las investigaciones practicadas se dedujera la oportunidad de decidir la expulsión, se daría traslado de la propuesta motivada y por escrito al interesado, para que alegara lo que considerase adecuado, en el plazo de cuarenta y ocho horas. En los supuestos en los que se hubiera procedido a la detención preventiva del extranjero, éste tendría derecho a asistencia letrada, que se le proporcionaría de oficio, en su caso, y a ser asistido por intérprete, si no comprendiera o hablara el castellano, y de forma gratuita en el caso de que careciese de medios económicos.

Sobre este precepto - que ya no se encuentra vigente- cabe hacer las siguientes consideraciones. En primer lugar, hay que resaltar el dato de que la asistencia letrada se vincula al hecho de la detención preventiva, no a la tramitación del procedimiento de expulsión, por lo que si no se produce la detención, no resulta aplicable la previsión normativa. Indudablemente con ello el legislador pretendía hacer efectiva la garantía del art. 17 CE.

En segundo lugar, indudablemente el legislador se inspiró en la regulación de la Ley de Enjuiciamiento Criminal. De hecho, existe una estrecha relación entre la detención preventiva y el internamiento previsto en el art. 26.2.2 previa autorización del Juez de Instrucción. Ya no es simplemente el derecho a 
contar con asistencia letrada, sino que se trata de un derecho de contenido prestacional en virtud del cual los poderes públicos están obligados a proporcionar de oficio un abogado al interesado, salvo que éste disponga de uno.

En tercer lugar, la asistencia jurídica constituye una obligación para los poderes públicos, siendo irrelevante el hecho de que el interesado disponga o no de medios económicos. Si no dispone de ellos, la asistencia será gratuita. Si dispone de los mismos, se supone que estaría obligado a pagar los correspondientes honorarios.

La Ley de 1985 fue derogada y sustituida por la Ley orgánica 4/2000 de 11 de enero, sobre derechos y libertades de los extranjeros y su integración social. Pues bien, el 20.1, denominado "derecho a la asistencia jurídica gratuita", establecía que "los extranjeros tienen derecho a asistencia letrada de oficio en los procedimientos administrativos o judiciales que puedan llevar a la denegación de su entrada o a su expulsión o salida obligatoria del territorio español y en todos los procedimientos en materia de asilo. Además, tendrán derecho a la asistencia de intérprete si no comprenden o hablan la lengua oficial que se utilice". Nótese la amplitud del derecho, pues ni siquiera menciona que la gratuidad se someta a determinados requisitos de insuficiencia de medios económicos.

Tras la reforma producida por la Ley orgánica 8/2000 de 22 de diciembre, el precepto pasó a ser el art. 22.1, con siguiente redacción: "1. Los extranjeros que se hallen en España y que carezcan de recursos económicos suficientes según los criterios establecidos en la normativa de asistencia jurídica gratuita tienen derecho a ésta en los procedimientos administrativos o judiciales que puedan llevar a la denegación de su entrada, a su devolución o expulsión del territorio español y en todos los procedimientos en materia de asilo. Además, tendrán derecho a la asistencia de intérprete si no comprenden o hablan la lengua oficial que se utilice" 38 .

El art. 63.3, que guarda una indudable conexión con lo dispuesto en la Ley de 1985, insiste en que en los procedimientos preferentes de expulsión se garantizará el derecho del extranjero a asistencia letrada, que se le proporcionará de oficio, en su caso, y a ser asistido por intérprete, si no comprende o no habla castellano, y de forma gratuita en el caso de que careciese de medios económicos.

\footnotetext{
${ }^{38}$ La última reforma de la Ley de Extranjería (Ley orgánica 2/2009 de 1 de diciembre) ha introducido una nueva modificación para tratar separadamente el derecho a la asistencia letrada en el procedimiento administrativo y en la vía judicial. Además, en vez de hablar de procedimientos en materia de asilo, habla de procedimientos en materia de protección internacional.
} 
Esta nueva regulación incluye importantes novedades con respecto a la Ley de 1985. En primer lugar, ya no se habla de un derecho a la asistencia jurídica, que se presupone, sino que el acento se pone en la gratuidad de la misma. Es decir, se incide en la idea de un derecho de naturaleza prestacional.

En segundo lugar, hay una remisión a lo dispuesto en la legislación de asistencia jurídica gratuita.

En tercer lugar, se desliga la cuestión de la idea de detención, poniéndose el acento en los fines del procedimiento (los que puedan llevar a la denegación de entrada, a la expulsión o a la devolución; así como los procedimientos en materia de asilo). De hecho, es posible la tramitación de estos procedimientos sin necesidad de que se produzca la detención del interesado.

En cuarto lugar, varios de estos procedimientos, como los de devolución y denegación de entrada, así como los procedimientos en materia de asilo, carecen de contenido sancionador. Lo que tienen en común es que dan o pueden dar lugar a la restricción de la libre circulación. Pero esto también ocurre con otros procedimientos en materia de extranjería (por ejemplo, denegaciones de autorización de residencia).

En quinto lugar, hay que destacar la diferencia de matices que se observa entre los art. 22.1 y 63.3. Este último, en efecto, pone el acento, exclusivamente en relación con los procedimientos preferentes de expulsión, en la garantía del derecho a asistencia letrada, que se le proporcionará de oficio, en su caso, lo que hace pensar en la plena analogía con lo dispuesto en el ámbito del proceso penal, en el sentido de que los poderes públicos deben garantizar en todo caso la intervención letrada, hasta el punto de poderse considerar como un derecho irrenunciable (ver art. 520.2.e de la Ley de Enjuiciamiento Criminal).

Por otra parte, los extranjeros sometidos a internamiento (en los centros de internamiento) tienen derecho, entre otros, "a ser asistido de abogado, que se proporcionará de oficio en su caso, y a comunicarse reservadamente con el mismo, incluso fuera del horario general del centro, cuando la urgencia del caso lo justifique" (art. 62 bis.f de la Ley de extranjería) ${ }^{39}$.

\footnotetext{
${ }^{39}$ Esta precepto fue introducido por la Ley orgánica 14/03 de 20 de noviembre. No obstante, ya se contemplaba anteriormente en el 27.2.d) de la Orden de 22-02-99, sobre normas de funcionamiento y régimen interior de los Centros de Internamiento de Extranjeros. Esta Orden ha sido parcialmente anulada por STS 11-05-05 (Ar. 6241), por insuficiencia de rango.
} 
Con independencia de todo lo anterior, debe hacerse mención al art. 20.3, según el cual en los procedimientos administrativos estarán legitimadas para intervenir como interesadas las organizaciones constituidas legalmente en España para la defensa de los inmigrantes, expresamente designadas por éstos. Lo cual supone dar entrada a estas organizaciones no ya en ejercicio de la defensa del extranjero, sino como sujetos interesados, lo que supone un evidente reforzamiento de su posición en el procedimiento administrativo en cuestión.

\section{La Ley de Violencia de Género}

El art. 20 de la Ley orgánica 1/2004 de 28 de diciembre, de medidas de protección integral contra la violencia de género, contempla la "asistencia jurídica". En él se establece que las mujeres víctimas de violencia de género que acrediten insuficiencia de recursos para litigar, en los términos establecidos en la Ley de asistencia jurídica gratuita, tienen derecho a la defensa y representación gratuitas por abogado y procurador en todos los procesos y procedimientos administrativos que tengan causa directa o indirecta en la violencia padecida, añadiendo que en estos supuestos una misma dirección letrada asumirá la defensa de la víctima.

En lo que se refiere a la asistencia jurídica gratuita en el ámbito judicial, la nueva regulación es superflua, pues no añade nada a lo que ya decía la LAJG, salvo la mención a una misma dirección letrada.

Por el contrario, supone una novedad la previsión de la asistencia jurídica gratuita en los procedimientos administrativos, siguiendo la estela marcada por la legislación de extranjería y asilo.

Cabe observar también que, al igual que en materia de extranjería y asilo, alude a la intervención del procurador no solo en los procesos, sino también en los procedimientos administrativos. Por de pronto, parece criticable que la intervención en los procedimientos administrativos se amplíe a los procuradores. Pero es que además la Ley muestra una clara falta de criterio, ya que, curiosamente, al procurador se le menciona en un primer momento, y a continuación se le olvida, hablando únicamente de la defensa (no de la representación) y de los honorarios (no de los derechos) ${ }^{40}$.

\footnotetext{
${ }^{40}$ En efecto, el art. 20.1 añade que "en todo caso, se garantizará la defensa jurídica, gratuita y especializada de forma inmediata a todas las víctimas de violencia de género que lo soliciten, sin perjuicio de que si no se les reconoce con posterioridad el derecho a la asistencia jurídica gratuita, éstas deberán abonar al abogado los honorarios devengados por su intervención", olvidando así al procurador. Lo mismo ocurre con el art. 20.4, según el cual "los Colegios de Abogados adoptarán las medidas necesarias para la designación urgente de letrado de oficio en los procedimientos que se sigan por violencia de género".
} 
La previsión de una misma dirección letrada puede ser contraproducente en ciertos casos, en los que sea necesaria una especialización en determinadas materias (Seguridad Social, laborales, administrativas, penales, etc), aunque como criterio puede ser válido. Pero se refiere solo a la asistencia jurídica gratuita o a la intervención de letrado de oficio, no a los demás supuestos.

Asimismo cabe observar que se da excesiva relevancia a los abogados, cuando en los procedimientos administrativos pudiera ser más eficaz la intervención de otros profesionales (graduados sociales en el ámbito de la Seguridad Social, trabajadores sociales).

\section{LA NO PREVISIÓN DE LA INTERVENGIÓN DE LETRADO EN LOS SUPUESTOS DE DETENGIÓN POR INFRACGIÓN DE LA LEGISLACIÓN ADMINISTRATIVA}

La privación o restricción de la libertad (art. $17 \mathrm{CE}$ ) puede tener diversas causas o finalidades lícitas ${ }^{41}$ : puede tener lugar en el ámbito de un proceso penal, pero también puede tener lugar en otros ámbitos (por ejemplo, detención de menores huidos; detención de enfermos mentales) ${ }^{42}$. En este momento nos interesa la que se produce en ejercicio de potestades administrativas. Piénsese en supuestos tales como la realización de pruebas de alcoholemia (en materia de tráfico y circulación vial), la identificación de una persona o los registros de vehículos o cacheos superficiales (en materia de seguridad ciudadana) o por motivos sanitarios (art. 26 y 28 de la Ley General de Sanidad, art. 9.2 de la Ley 41/02 de 14 de noviembre) o en materia de extranjería (art. 61.1.d de la Ley de Extranjería). ¿Rigen en tal caso las garantías recogidas en el art. 17 CE, y en particular la asistencia de letrado?

En principio, podría pensarse que el derecho a la asistencia letrada contemplado en el art. 17.3 CE es siempre exigible. El Tribunal Constitucional en alguna de sus sentencias ha mantenido un concepto muy amplio de detención, entendiendo por tal cualquier situación en que la persona se vea obstaculizada para autodeterminar, por obra de su libertad, una conducta lícita, de suerte que la detención no es una decisión que se adopte en el curso de un procedimiento, sino una pura situación fáctica, sin que puedan encontrarse zonas intermedias entre detención y libertad (STG 98/86).

\footnotetext{
${ }^{41}$ Sobre esta cuestión, SALIDO VALLE, G., La detención policial, Ed. Bosch, Barcelona, 1997, pág. 43 ss.

${ }^{42} \mathrm{El}$ art. 5.1 CEDH es muy amplio en este sentido, contemplando diversas causas de privación de libertad.
} 
Con ello se reaccionaba frente a una doctrina tradicional que introducía una tercera situación entre la libertad y la detención, la retención, a la que no era aplicable el régimen jurídico de la detención.

No obstante, el propio Tribunal Constitucional en seguida introdujo matices a un concepto amplio de detención en casos como los de la prueba de alcoholemia a conductores.

Así, la STC 107/85 dice que los derechos declarados en el art. 17.3 de la norma fundamental corresponden al «detenido», esto es, a quien haya sido privado provisionalmente de su libertad por razón de la presunta comisión de un ilícito penal y para su puesta a disposición de la autoridad judicial en el plazo máximo de setenta y dos horas, de no haber cesado antes la detención misma, según prescribe el núm. $2 .^{\circ}$ del mismo artículo. Las garantías exigidas por el art. 17.3 -información al detenido de sus derechos y de las razones de su detención, inexistencia de cualquier obligación de declarar y asistencia letrada- hallan, pues, su sentido en asegurar la situación de quien, privado de su libertad, se encuentra ante la eventualidad de quedar sometido a un procedimiento penal, procurando así la norma constitucional que aquella situación de sujeción no devenga en ningún caso en productora de la indefensión del afectado. No es esta situación, sin embargo, -añade la sentencia- la de quien, conduciendo un vehículo de motor, es requerido policialmente para la verificación de una prueba orientativa de alcoholemia, porque ni el así requerido queda, sólo por ello, detenido en el sentido constitucional del concepto, ni la realización misma del análisis entraña exigencia alguna de declaración autoincriminatoria del afectado, y sí sólo la verificación de una pericia técnica de resultado incierto y que no exorbita, en sí, las funciones propias de quienes tienen como deber la preservación de la seguridad del tránsito y, en su caso, en mérito de lo dispuesto en el art. $492.1^{\circ}$ de la Ley de Enjuiciamiento Criminal, la detención de quien intentare cometer un delito o lo estuviere cometiendo. En estos términos, la verificación de la prueba que se considera supone, para el afectado, un sometimiento, no ilegítimo desde la perspectiva constitucional, a las normas de policía, sometimiento al que, incluso, puede verse obligado sin la previa existencia de indicios de infracción, en el curso de controles preventivos realizados por los encargados de velar por la regularidad y seguridad del tránsito. Y concluye la sentencia diciendo que "la realización de esta prueba, por lo tanto, así como la comprobación de otro modo por agentes del orden público de la identidad y estado de los conductores, no requiere de las garantías inscritas en el art. 17.3 de la norma fundamental, dispuestas específicamente en protección del detenido y no de quienquiera que se halle sujeto a las normas de policía de tráfico". 
La STC 22/88 sigue la misma doctrina: "el sometimiento de los conductores de vehículos a las normas del Código de la Circulación y, por tanto, a las autoridades encargadas de su cumplimiento, en cuanto no desborden -como ocurre en este caso- el campo de actuación que les es propio, no guardan relación alguna con el derecho a la libertad que consagra y protege el art. 17 de la Constitución”, remitiéndose a continuación a la doctrina de la STC 107/1985, y concluyendo que "no se da, pues, la vulneración del art. 17 de la Constitución que denuncia el recurrente, porque la práctica por él aceptada de la prueba de alcoholemia no guarda relación alguna con la privación de libertad a que se refiere el apartado 1 de dicho precepto".

La STC 252/94, conforme a la citada doctrina, concluye que en estos casos de pruebas de alcoholemia la asistencia letrada no es condición de validez -desde la perspectiva constitucional- de la práctica de dicha prueba ${ }^{43}$.

Posteriormente diversas providencias inadmitieron recursos de amparo en casos de prácticas policiales de cacheo e identificación ${ }^{44}$.

La STC 341/93, al plantearse la cuestión de la constitucionalidad de la Ley de Protección de la Seguridad Ciudadana en lo referente a la identificación de personas, insiste en esta dirección: el art. $17 \mathrm{CE}$ en principio se refiere a las detenciones judiciales, pero no a otro tipo de detenciones, como por ejemplo, la efectuada para identificar a un interesado, a pesar de que en estos casos la privación de libertad puede no ser ya momentánea, sino tener una cierta duración. Y por ello no exige en tal caso la asistencia de abogado, a la que en principio se refiere el art. 17.3. Según la STC, "no resulta inexcusable que la identificación misma haya de llevarse a cabo necesariamente en presencia o con la asistencia de abogado, garantía ésta cuya razón de ser está en la protección del detenido y en el aseguramiento de la corrección de los interrogatorios a que pueda ser sometido (STG 196/87, FJ 2')". Continúa diciendo la sentencia que ninguna de estas garantías constitucionales -recordatorio del derecho a no declarar y asistencia obligatoria de abogado- son indispensables para la verificación de unas diligencias de identificación que, vale reiterar, no permiten interrogatorio alguno que vaya más allá de la obtención de los «datos personales» a los que se

\footnotetext{
${ }^{43}$ No obstante, en la propia sentencia el Tribunal Constitucional considera que esa doctrina debe matizarse cuando la prueba se pretende realizar con una persona que se encuentra privada de libertad, en situación de detención preventiva ante la eventualidad de quedar sometido a un procedimiento penal, por una decisión policial.

${ }^{44}$ CASTILLO BLANCO, F., La Ley de Seguridad Ciudadana: Reflexiones sobre algunos puntos controvertidos, en la Revista de Administración Pública 130, 1993, pág. 452.
} 
refiere el repetido art. 9.3 de la Ley de Protección de la Seguridad Ciudadana. Como consecuencia, consideró que el art. 20.2 de la citada Ley no era inconstitucional.

En igual sentido se ha venido pronunciando el Tribunal Supremo, aunque poniendo el acento en el dato de la momentánea paralización de la actividad cotidiana del ciudadano. Según la STS 9-04-1999 (Ar. 3111), debe distinguirse entre la detención contemplada en el art. $17 \mathrm{CE}$, y las simples retenciones o provisionales restricciones de la libertad que requieren de modo inevitable la práctica de determinadas diligencias no dirigidas en principio contra la libertad ambulatoria strictu sensu, como sucede con las pruebas de alcoholemia, la identificación o los cacheos, diligencias policiales que se hallan amparadas por el artículo 11.1 f) y g) de la Ley Orgánica 2/1986, de Fuerzas y Cuerpos de Seguridad (STS de 27 de septiembre de 1996, entre otras muchas). En el mismo sentido, la STS de 15 de abril de 1993 (Ar. 3334) recuerda que "no es posible equiparar la privación de libertad a que se refiere el art. 17 de la Constitución con la presencia física de una persona en las dependencias policiales para la práctica de una diligencia por el tiempo estrictamente necesario para llevarla a efecto", y que la diligencia de cacheo -superficial- e identificación no está sujeta a las mismas formalidades que la detención ${ }^{45}$.

De todo ello cabe concluir que la jurisprudencia acoge un concepto restrictivo de la detención, limitada a la detención como medida cautelar dirigida a fines propios del proceso penal, que se contrapone a la medida gubernativa, a la que no es aplicable lo dispuesto en los apartados 2 y 3 del art. $17 \mathrm{CE}^{46}$. La conclusión de todo ello es clara: si en tales casos no cabe hablar de la detención contemplada en el art. $17 \mathrm{CE}$, no cabe invocar un derecho fundamental a la asistencia de abogado.

Ahora bien, esto supuesto, ocurre que la posibilidad de asesoramiento se encuentra prevista por la Ley de régimen jurídico de las Administraciones públi-

\footnotetext{
45 Vid. también STS (Sala de lo Penal) de 2 de febrero de 1996 (Ar. 789), 7 de julio de 1995 (Ar. 5389), 24 de mayo de 1996 (Ar. 4020), 4-06-1997 (Aranz. 4564). Sobre ello, AGIRREAZKUENAGA, I. y ARTETXE PALOMAR, E., Sintesis en materia de orden y seguridad, en la Revista Vasca de Administración Pública, 61, 2001, pág. 255.

46 Sobre el concepto restrictivo, vid SANTAOLALLA LÓPEZ, F., Identificación del indocumentado: comentario del art. 20 de la Ley orgánica 1/1992 de 21 de febrero, en la Revista Española de Derecho Administrativo (REDA) 80, 1993, pág. 640 ss, con cita de jurisprudencia. Se habla también de una inmovilización del ciudadano por el tiempo imprescindible para la práctica de una diligencia policial como consecuencia del sometimiento a las normas de policía (C. SALIDO, op. cit., pág. 177 y 181).
} 
cas y del procedimiento administrativo común con carácter general en las actuaciones administrativas. Sobre esta base, ¿cabe reclamar por parte de un interesado la asistencia jurídica? En principio, no parece que pueda negarse tal derecho, siempre que ello no suponga ir contra la propia naturaleza de las cosas. Por ejemplo, en un control de alcoholemia o en un cacheo, si el interesado va acompañado de abogado o puede disponer de él sin demora, la Administración actuante no puede negarse a que éste preste asistencia. En cambio, carecería de sentido tener que suspender el control de cuestión hasta que pudiera encontrarse presente alguien para asesorar al interesado.

Por otra parte, la asistencia jurídica en determinados supuestos de privación de libertad no momentánea por parte de la Administración se encuentra expresamente contemplada. Piénsese en la detención del extranjero, contemplada como tal detención en el art. 61.1d) de la Ley de Extranjería, o en el internamiento (art. 61.1.e).

En ocasiones la detención puede producirse por hechos sobre los que en un primer momento puede ser difícil discernir si pueden ser constitutivos de infracción penal o administrativa. Por ejemplo, si hay una prueba de alcoholemia, en principio puede desconocerse si de ello va a poder derivar una responsabilidad penal o administrativa; lo mismo ocurre en los casos de tráfico o consumo de estupefacientes. La detención incluso puede dar lugar a consecuencia penales (por ejemplo, por un delito de resistencia o desobediencia). La cuestión es importante, porque si lo que se imputa es un hecho punible, el derecho a la defensa surge desde el primer momento (art. 118 de la Ley de Enjuiciamiento Criminal) ${ }^{47}$.

En cualquier caso, en los supuestos de restricciones administrativas a la libertad no existe una regulación específica de los derechos de los interesados, ya que la regulación sobre la detención se encuentra fundamentalmente en la Ley de Enjuiciamiento Criminal (art. 520-527). Existe por ello una tendencia a aplicar las normas de esta Ley a todo tipo de detenciones por actuaciones administrativas.

Por otra parte, la jurisprudencia ha impuesto ciertos límites. Así, como hemos visto, la STC 341/93 ha señalado que la detención para identificación

\footnotetext{
47 Vid. la precisión de la STC 107/85, según la cual sólo tras el resultado positivo de la prueba de alcoholemia, de la que surgen indicios de responsabilidad penal, cabe hablar técnicamente de detención, con los efectos previstos en el art. 17.3 CE.
} 
prevista en la Ley de Protección de la Seguridad Ciudadana lo es a esos solos efectos, de lo que cabe deducir que si como consecuencia de la identificación procede realizar nuevas actuaciones, ya nos estamos moviendo en otro nivel, en el que sí puede ser invocado el derecho a la asistencia jurídica.

En este sentido, la sentencia de la Sala de lo Contencioso Administrativo de Granada de 2-09-02 (Ar. 2002/279906) alude a un caso en que se detuvo a una persona para su identificación (por tenencia ilícita de cocaína) tomándosele declaración en las dependencias policiales sin asistencia de abogado: la sentencia dice que esta actuación no se ajusta al $17 \mathrm{CE}$, niega validez y eficacia al acta de la declaración - por ser una prueba ilícitamente obtenida- y en consecuencia, al no existir otro dato en contra, anula la sanción.

\section{BIBLIOGRAFÍA}

AGIRREAZKUENAGA, I. y ARTETXE PALOMAR, E., Sintesis en materia de orden y seguridad, en Revista Vasca de Administración Pública, 61, 2001, pág. 237 SS.

ALARCÓN SOTOMAYOR, A.: El procedimiento administrativo sancionador y los derechos fundamentales, Thomson-Civitas, Cizur Menor, 2007.

BLANQUER, D.: Asilo político en España. Garantías del extranjero y garantías del interés general, Civitas-Ministerio del Interior, Madrid, 1997.

CASTILLO BLANCO, F.: La Ley de Seguridad Ciudadana: Reflexiones sobre algunos puntos controvertidos, en Revista de Administración Pública, 130, 1993, pág. 423 SS.

FERNÁNDEZ SEGADO, F., El nuevo régimen disciplinario militar: reflexiones en torno a la obra "Comentarios a la Ley Disciplinaria de las Fuerzas Armadas", en Revista Española de Derecho Militar, 76, julio diciembre 2000, pág. 125 ss.

GARBERÍ LLOBREGAT, J., Constitución y Derecho Procesal. Los fundamentos constitucionales del Derecho Procesal, Cuadernos Civitas, Madrid 2009.

GARCÍA GÓMEZ DE MERCADO, F.: Sanciones administrativas, Ed. Comares, Granada, 2008.

GONZÁLEZ NAVARRO, F.: Derecho Administrativo español, tomo III, EUNSA, Pamplona, 1997.

GONZÁLEZ PÉREZ, J. y GONZÁLEZ NAVARRO, F.: Comentarios a la Ley de régimen jurídico de las Administraciones públicas y del procedimiento administrativo comun, Ed. Thomson-Civitas, Madrid, 2007, tomo II.

GUERRERO FERNÁNDEZ, P.: Designación de abogado de oficio y justicia gratuita, en PICÓ JUNOY, J. (dir.), Presente y futuro del proceso civil, Bosch editor, Barcelona, 1998, pág. 199 ss. 
MORENO TRAPIELLA, P.: El control judicial de las sanciones administrativas en el convenio europeo de derechos humanos, en Documentación Administrativa, 280-281, 2008.

REQUERO IBÁÑEZ, J.L.: La justicia gratuita en el orden contencioso administrativo, en VVAA, Fusticia gratuita, Cuadernos de Derecho Judicial, vol. 24, 1995.

SALIDO VALLE, G.: La detención policial, Ed. Bosch, Barcelona, 1997.

SANTAOLALLA LÓPEZ, F.: Identificación del indocumentado: comentario del art. 20 de la Ley orgánica 1/1992 de 21 de febrero, en la Revista Española de Derecho Administrativo, (REDA) 80, 1993, pág. 635 ss.

TARRAGA POVEDA, J.: La representación y defensa en juicio por graduado social, Ed. Laborum, Murcia, 2001.

TRAYTER JIMÉNEZ, J.M.: El procedimiento administrativo sancionador, en Fusticia Administrativa, Revista de Derecho Administrativo, número extraordinario, 2001, pág. 75 ss. 